\title{
Tarihi Yapılarda Yeniden İşlevlendirme Süreçlerine Sistematik Bir Yaklaşım; Atik Valide Külliyesi Örneği
}

\author{
İzzettin Kutlu ${ }^{1 *}$, Ruşen Ergün ${ }^{2}$ \\ 1* Mardin Artuklu Üniversitesi, Mühendislik-Mimarlık Fakültesi, Mimarlık Bölümü, Mardin, Türkiye, (ORCID: 0000-0002-5546-5548), izzettinkutlu @ artuklu.edu.tr \\ ${ }^{2}$ Dicle Üniversitesi, Mimarlık Fakültesi, Mimarlık Bölümü, Diyarbakır, Türkiye (ORCID: 0000-0001-5253-3245), rusen.ergun@ dicle.edu.tr
}

(İlk Geliş Tarihi 02 Mart 2021 ve Kabul Tarihi 27 Haziran 2021)

(DOI: $10.31590 /$ ejosat.889402)

ATIF/REFERENCE: Kutlu, İ. \& Ergün, R. (2021). Tarihi Yapılarda Yeniden İşlevlendirme Süreçlerine Sistematik Bir Yaklaşım; Atik Valide Külliyesi Örneği. Avrupa Bilim ve Teknoloji Dergisi, (25), 172-184.

\begin{abstract}
Öz
Tarihi yapılar; toplumun kültürü, mimarisi, sosyo-ekonomik durumu, yaşayış biçimi gibi bölge geçmişine dair bilgi veren önemli eserlerdir. Fakat zaman içerisinde iklim ve kullanım koşullarına bağlı olarak doğal veya insan kaynaklı nedenlerden bozulmalar meydana gelebilmektedir. Bozulmalara karşı ayakta kalabilen tarihi yapılar, aynı işlevle korunarak restore edilebilmekte veya çağdaş döneme ayak uydurabilmeleri adına eski kullanımının dışında farklı olarak yeniden işlevlendirilebilmektedir. Bu çalışmanın amacı da tarihi yapıların özelliklerine göre müdahalelerin ve işlev değişikliklerinin mimari uyumluluğunu belirlemektir. Çalışmada, Mimar Sinan'ın son eseri olarak bilinen Atik Valide Külliyesindeki birimlerin inşa edildiği dönemden günümüze kadar geçirmiş olduğu değişimler araştırılmıştır. Çalışmanın yöntemi iki aşamadan oluşmaktadır. İlk aşamada veri toplama yöntemi kullanılarak Atik Valide Külliye yapılarının özgün ve mevcut durum özellikleri değerlendirilmiştir. İkinci aşamada ise iz sürme yöntemi ile tarihi yapılarda değiş̧en kütle ve işlev ilişkileri tespit edilmiştir. Tarihi külliye yapılarında işlev değişiklikleri çizelgeler oluşturularak dönemlere ayrılmıştır. Yapılardaki dönemsel müdahalelerin, önemli bir mimari miras olan külliye yapılarına olumlu ve olumsuz yaklaşımları; çeşitli uluslararası koruma ölçütlerinin maddeleri referans alınarak işlevsel performans, süreç performans ve çevresel performans kriterleri başlığında değerlendirilmiştir. Uygulanan yöntem, ortaya çıkan kültürel miras etki değerlendirmesi alanına bir katkı olarak ve yerel yönetimlere değerleme için sunulan belirli kültürel miras varlık projelerini değerlendirmek için bilimsel yardım olarak düşünülebilir. Sonuç olarak; kültürel değeri olan bir külliye özelinden tarihi yapı geneline yapılacak olan işlev değişikliklerinde, yapının kütlesel ölçeği ile uyumlu olmayan dönüşümler yerine; yapının tümüyle orantılı uyumlu bir işlevin seçilmesi, yeni işlevin tarihsel örüntü duygusunu tamamlaması ve yapının korunmasına katkıda bulunması gerektiği sonucuna varılmıştır.
\end{abstract}

\section{A Systematic Approach for Re-Using Processes in Historical Buildings; Example of Atik Valide Kulliye}

\begin{abstract}
Historical buildings are important works that provide information about the past of the region such as the culture, architecture, socioeconomic status and lifestyle of the society. However, over time, depending on the climate and conditions of use, deterioration may occur from natural or human causes. Historical buildings that can survive against deterioration can be preserved and restored with the same function, or they can be re-using differently than their original use in order to adapt to the contemporary period. The aim of this study is to determine the architectural compatibility of interventions and functional changes according to the characteristics of historical buildings. In the study, the changes that the Atik Valide Kulliye, known as the last work of Mimar Sinan, has been investigated from the time it was built to the present day. The method of the study consists of two stages. In the first stage, the original
\end{abstract}

* Sorumlu Yazar: izzettinkutlu@artuklu.edu.tr 
and current status characteristics of the Atik Valide Kulliye structures were evaluated using the data collection method. In the second stage, changing mass and function relationships in historical buildings were determined by tracing method. Schedules of functional changes in historical külliye buildings are divided into periods. The positive and negative approaches of the periodic interventions in the buildings to the külliye structures, which are an important architectural heritage; It has been evaluated under the heading of functional performance, process performance and environmental performance criteria, taking as reference the articles of various international protection criteria. The method applied can be considered as a contribution to the emerging field of cultural heritage impact assessment and as scientific assistance to assess specific cultural heritage property projects submitted to local governments for appraisal. As a result, reusing in historical buildings, a function that is compatible with the whole structure should be selected, unlike transformations that are not compatible with the mass scale of the building. It is concluded that the new function should complement the sense of historical pattern and contribute to the preservation of the structure.

Keywords: Atik Valide Kulliye, Architect Sinan, Conservation of architectural heritage, Performance evaluation criteria.

\section{Giriş}

Anadolu'da yapım faaliyetlerinin en etkin olduğu dönem, Mimar Sinan'ın Hassa Mimarlar Ocağı'nın başında bulunduğu 1538-1588 Osmanlı yıllarıdır. Dönemin yapıları, hem tasarımların üstün düzeyi ve amaca uygunlukları hem de iş gücünün ve malzeme kaynaklarının iyi örgütlenmesiyle başarıya ulaşmıştır. Mimar Sinan Osmanlı Devleti'nde yaptığ 1 mimarlık görevi boyunca, yapılarında gerçekleştirdiği deneyler ve getirdiği yenilikler ile Türk mimarlık tarihinin en büyük ismi olarak anılmaktadır (Ahunbay, 1988a).

1489-90 yıllarında Kayseri-Ağırnaz ilçesinde doğan Mimar Sinan, babasının yanında taş ustası ve marangoz olarak çalışmış, 1512 'de Yeniçeri ocağına katılmıştır. Bu katılım sonrasında, Osmanlı sarayına ve özellikle Kanuni Sultan Süleyman'a (hükümdarlık dönemi 1520-66) ömrü boyunca hizmet etmiştir. İnşaa faaliyetleri, Osmanlı İmparatorluğu'nun altın çağını yaşadığı döneme denk gelmesinden son derece elverişli koşullarda başlamıştır. Kariyerinin başlangıcında, ilk İslam imparatorluklarının sütunlu veya İran-İslami dört eyvanlı camilerinin aksine Bizans etkisinde kubbeli camiler inşa etmiştir (Rabb, 2013). Özellikle büyüklüğü, mimari tasarımı ve sembolik gücü nedeniyle Ayasofya, Mimar Sinan'a ilham veren en önemli yapılardan biri olmuştur. Sinan mimarlık sürecinde; 79 cami, 34 saray, 33 hamam, 19 türbe, 55 okul, 16 imarethane, 7 medrese, 12 kervansaray, tahıl ambarları, çeşmeler, su kemerleri ve hastaneler yapmıştır (Britannica, 2020).

Sinan'ın 'çıraklık eseri' olarak adlandırdığı ve 1548 yılında inşası tamamlanan Şehzade Camii, Sinan'1n ilk önemli mimari organizasyonlarındandır. İstanbul'daki Süleymaniye Camii ise 1550-57 yıllarında inşa edilmiş ve Mimar Sinan tarafindan 'kalfalığının' en önemli eseri; 1569-75 yıllarında inşa ettiği Edirne'deki Selimiye Camii'yi ise 'ustalık' döneminin en büyük eseri olarak adlandırmıştır (Yılmaz, 2001). Bu çalışmada incelenen Atik Valide Külliyesi, Selimiye Camii’nin inşa edildiği dönemde yapımına başlansa da tamamlanma tarihi göz önüne alındığında Mimar Sinan'ın son eseri özelliğini taşımaktadır (Altıntaş, 2020).

Mimar Sinan hakkında yapılan çok sayıda çalışma olsa da, son eseri Atik Valide Külliyesi özelinde yapılan, yapısal özelliklerin tanımlandığı ve yapıların değişim süreçlerinin ele alındığı güncel bir çalışma bulunmamaktadır (Tablo I).
Tablo I. Mimar Sinan ve eserleri hakkında yapılan çalışmalar

\begin{tabular}{|c|c|c|}
\hline Yapı Tipi & Yazarlar & Çalış̧manın Adı \\
\hline \multirow[t]{14}{*}{ Camiler } & $\begin{array}{l}\text { Sadan, Bal } \\
\text { and Smyrou, } \\
2007\end{array}$ & $\begin{array}{l}\text { Structural Analysis of Istanbul } \\
\text { Beyazit II Mosque Retrofitted by } \\
\text { Mimar Sinan }\end{array}$ \\
\hline & Yağl1, 2010 & Mimar Sinan'ın Şehzade, \\
\hline & & $\begin{array}{l}\text { Süleymaniye ve Selimiye } \\
\text { camilerinin tektonik karakterlerinin } \\
\text { çözümlenmesi }\end{array}$ \\
\hline & Tuncer, 2014 & $\begin{array}{l}\text { Mimar Sinan camilerinde kubbenin } \\
\text { akustik açıdan belgelenmesi: }\end{array}$ \\
\hline & & $\begin{array}{l}\text { Kadırga Sokollu Mehmet Paşa } \\
\text { camii örneği }\end{array}$ \\
\hline & & Mimar Sinan'ın Şehzade, \\
\hline & $\begin{array}{l}\text { Sönmez, } \\
2015\end{array}$ & 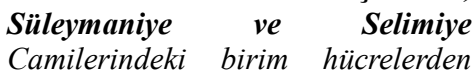 \\
\hline & & $\begin{array}{l}\text { üreyen geometrik desenlerin } \\
\text { çözümlemeleri }\end{array}$ \\
\hline & Çıplak, 2017 & Mimar Sinan yapılarının inşa \\
\hline & & tekniğini anlamak: Lüleburgaz \\
\hline & & $\begin{array}{l}\text { Sokullu Mehmed Paşa Camisi } \\
\text { örnek çalışması }\end{array}$ \\
\hline & $\begin{array}{l}\text { Kaygisiz, } \\
2019\end{array}$ & $\begin{array}{l}\text { Mimar Sinan Camilerinden Şemsi } \\
\text { Ahmet Paşa Camii (Üsküdar) ile } \\
\text { T.C. Diyanet Işleri Başkanliğ Tip } 3\end{array}$ \\
\hline & & $\begin{array}{l}\text { Camii'nin akustik açıdan } \\
\text { karşılaştırılması }\end{array}$ \\
\hline & Polat, 2020 & $\begin{array}{l}\text { Mimar Sinan dönemi camileri } \\
\text { içerisinde yer alan Diyarbakı } \\
\text { İskender Paşa Caminin önemi ve } \\
\text { koruma sorunlart }\end{array}$ \\
\hline \multirow[t]{6}{*}{ Külliyeler } & A. Yilmaz, & Osmanlı Mimarisinde Külliye \\
\hline & 2001 & $\begin{array}{l}\text { Olgusu ve Atik Valide Külliyesi } \\
\text { Örneği }\end{array}$ \\
\hline & Akgün, 2005 & $\begin{array}{l}\text { 16. yy. Osmanlı kenti İstanbul'da } \\
\text { kent içi konumlarına göre Mimar }\end{array}$ \\
\hline & & $\begin{array}{l}\text { Sinan'ın külliye gruplarında yer } \\
\text { seçimi etmenlerinin tespiti ve analizi }\end{array}$ \\
\hline & & Mimar Sinan yapısı menzil \\
\hline & $\begin{array}{l}\text { Sönmez, } \\
2010\end{array}$ & $\begin{array}{l}\text { külliyelerinden; İzmit Pertev Paşa } \\
\text { Külliyesi }\end{array}$ \\
\hline \multirow[t]{3}{*}{ Hamamlar } & $\begin{array}{l}\text { Ertuğrul, } \\
2002\end{array}$ & $\begin{array}{l}\text { Mimar Sinan'ın İstanbul'daki mevcut } \\
\text { hamamlart }\end{array}$ \\
\hline & $\begin{array}{l}\text { Demirdal, } \\
2014\end{array}$ & $\begin{array}{l}\text { İstanbul'da işlev değişikliğine } \\
\text { uğramıs Mimar Sinan Hamamları: } \\
\text { Ortaköy hamamı örneğ }\end{array}$ \\
\hline & İpekçi, 2016 & $\begin{array}{l}\text { Mimar Sinan tarafindan İstanbul'da } \\
\text { inşa edilen Çinili Hamam'ın sıva } \\
\text { özellikleri }\end{array}$ \\
\hline \multirow[t]{2}{*}{ Medreseler } & Dinçel, 1995 & $\begin{array}{l}\text { İstanbul'daki Mimar Sinan dönemi } \\
\text { medreseleri genel değerlendirmesi } \\
\text { ve Kılıç Ali Paşa Medresesi }\end{array}$ \\
\hline & Alkan, 2007 & $\begin{array}{l}\text { İstanbul Mimar Sinan Dönemi } \\
\text { Külliyeleri İçinde } \\
\text { Medreselerin Yeri }\end{array}$ \\
\hline
\end{tabular}


ve 'Edirnekapt Mihrimah Sultan Medresesi'

Benli, $2016 \quad$ Hospitals in the Ottoman Period and the Work Of Sinan the Architect: Suleymaniye Külliye Dar Al-Shifa and the Medical Madrasa

Sekitmez, Istanbul Mimar Sinan dönemi 2019 medreseleri ve Üsküdar Mihrimah Sultan medresesi koruma ve işlev sorunlart

\begin{tabular}{|c|c|c|}
\hline \multirow[t]{3}{*}{ Türbeler } & \multirow[t]{3}{*}{ Kaynar, 2019} & Restorasyon $\quad$ uygulamalart \\
\hline & & $\begin{array}{lcr}\text { sonrasinda } & \text { önleyici } & \text { koruma } \\
\text { metodolojisinin } & \text { Mimar } & \text { Sinan }\end{array}$ \\
\hline & & $\begin{array}{l}\text { dönemi türbeleri } \text { üzerinde } \\
\text { irdelenmesi }\end{array}$ \\
\hline \multirow{4}{*}{$\begin{array}{l}\text { Eğitim } \\
\text { Yapıları }\end{array}$} & Ahunbay, & Mimar Sinan Ĕgitim Yapıları \\
\hline & $1988 \mathrm{~b}$ & \\
\hline & Balcan, 2018 & Mimar Sinan'ın $\quad$ Istanbul \\
\hline & & $\begin{array}{l}\text { külliyelerinde yer alan sıbyan } \\
\text { mektepleri ve koruma sorunları }\end{array}$ \\
\hline \multirow[t]{2}{*}{ Köprüler } & Alaboz, 2008 & $\begin{array}{cc}\text { Mimar Sinan köprülerinin güncel } \\
\text { durum } & \text { değerlendirmesi }\end{array}$ \\
\hline & & $\begin{array}{l}\text { Kapuă̆ası köprüsü restorasyon } \\
\text { projesi }\end{array}$ \\
\hline
\end{tabular}

\section{Materyal ve Metot}

\subsection{Metot}

Atik Valide külliyesi; cami, darüşşifa, sıbyan mektebi, darulhadis, medrese, imaret, tabhane, tekke, kervansaray ve hamam olmak üzere 10 farklı işlevdeki yapıyı barındırması ile Anadolu'da bir külliyede farklı işlevdeki birçok yapıyı bir arada bulunduran külliyeler özelliğini taşımaktadır.

Bu makalede iki adet nitel araştırma yöntemi kullanılmıştır. Bunlar sırasıyla veri toplama ve iz sürme yöntemleridir. Veri toplama yöntemi, araştırma konusunu sonuca ulaştıracak bilgilerin elde edilmesi amacıyla kullanılan araştırma tekniğidir. Araştırma konusuna göre veri toplama, doküman incelenmesi, anket, görüşme, gözlem, deney gibi farklı yollarla gerçekleştirilebilir (Symon \& Cassell, 1998: Yıldırım, 1999). İz sürme yöntemi veya süreç izleme yöntemi ise bir durumun nedensel durumlarının sürecin de dahil edilerek incelendiği nitel araştırma yöntemidir. Hem veri toplama hem de örneklem çalışmalarının güvenirliğini sağlayan iz sürme yöntemi, belirli bir zaman diliminde ilgili araştırma konularının örgütsel süreçlerinin tanımlar. Araştırmaya konu olan sürecin özel durumları örneklenerek ölçütler oluşturulur (Bennett \& Elman, 2006: İşçi, 2008).

Çalışmada, Atik Valide külliyesindeki yapıların dönem içerisinde dönüşümleri araștırılmış ve bu dönüşümlerin Carta Del Restauro (1931), Venedik Tüzügü (1964), Washington Tüzüğü (1987), Burra Tüzüğü (1999) ve ICOMOS Geleneksel Mimari Miras Tüzüğü 1999-Uygulama İlkeleri kapsamında performans analiz değerlendirmeleri yapılmıştır. Bu araştırmada her birimin işlevsel ve süreç performans değerlendirmeleri ayrı ayrı yapılmış olup çevresel performans değerlendirmesi külliyenin tüm birimleri için ortak olarak ele alınmıştır.

\subsection{Materyal}

Atik Valide veya Valide-i Atik külliyesi olarak bilinen yap1 1570'li yıllarda Nurbanu Sultan tarafindan Mimar Sinan'a yaptırılmıştır (Çalışmada Atik Valide Külliyesi ismi kullanılacaktır). Bu yap1 Mimar Sinan'1n son eseri olarak bilinmektedir. Farklı işlevdeki yapıların bir arada inşa edildiği külliyelerden olan Atik Valide, İstanbul'un Üsküdar ilçesinde yer almaktadır (Eriş \& Yüzereroğlu, 2013; Katkak, 2016; Tanman, 1991; Kutlu \& Sever, 2017).

Atik Valide Külliye'si 1979 yılında tescil edilmiş ve 1992 yılında külliye ve yakın çevresi sit alanı ilan edilmiştir (Ekimci, 2011). Külliye Atik Valide Mahallesi, Tekkeönü sokak ile Eski toptaşı caddesi arasında kuzeydoğu-güneybatı yönünde uzanan alanda bulunmaktadır. Külliye, aralarında Toptaşı Meydan sokağın bulunduğu iki yapı grubundan oluşmaktadır. Cami, medrese, tekke bir grupta (A grubu), sıbyan mektebi, imaret, darüşşifa, hamam, tabhane ve kervansaray bir grupta bulunmaktadır (B grubu, Şekil 1a-b).

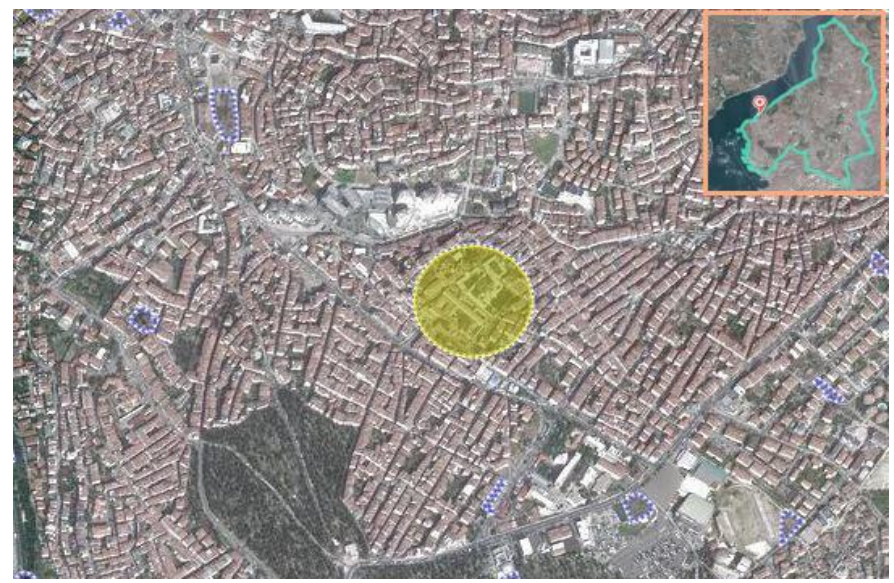

$\mathbf{a}$

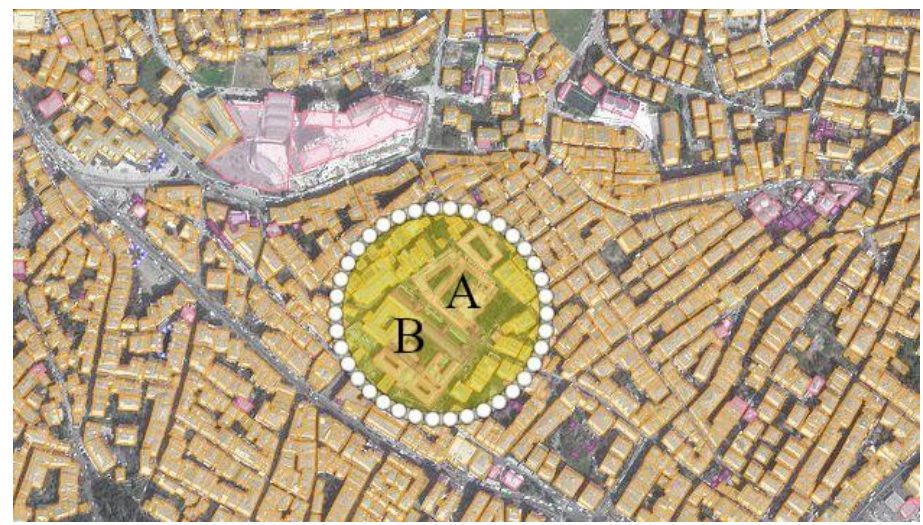

b

Şekil 1. Üsküdar - a) Külliyenin Üsküdar İlçesinde bulunduğu konumu, b) Atik Valide Külliye yapıları (Yandex haritalardan derlenmiştir)

Külliye Güneybatı'ya doğru eğimin arttığı bir yamacin üzerine konumlandırılmıştır. Yamacın en üst kotuna Cami, en alt kotuna ise kervansaray konumlandırılmıştır (Şekil 2a-b). Yılmaz (2001), külliyedeki birimlerin yamacın toplamda 4 farklı kotuna konumlandığını belirtmektedir. Üst kottan alt kota doğru;

1. Kot: Cami ve Medrese

2. Kot: Tekke, Darulhadis ve Mektep

3. Kot: Darüşşifa ve İmaret

4. Kot: Kervansaraylar bulunmaktadır (Y1lmaz, 2001). 


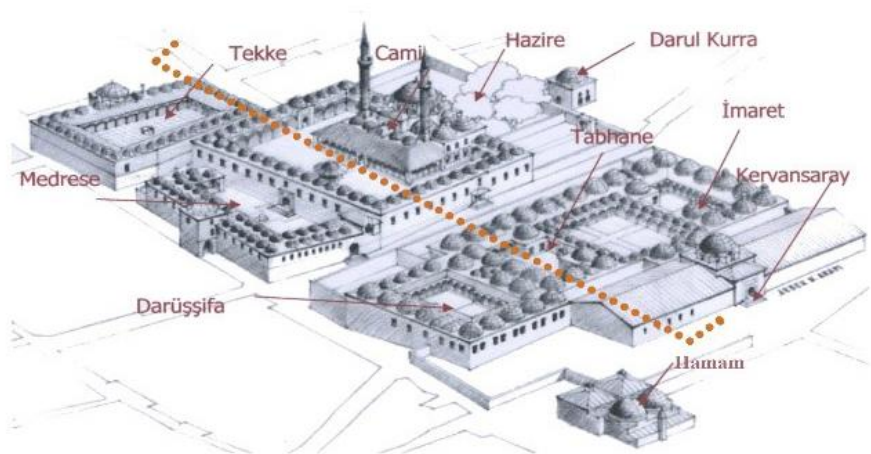

$\mathbf{a}$

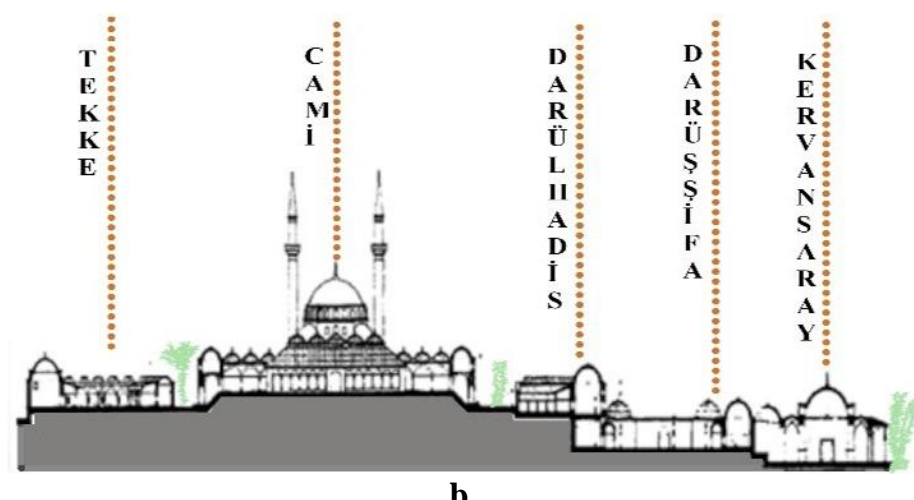

Şekil 2. Atik Valide Külliyesi - a) Külliye yapılarının birbirlerine göre bulunduğu izometrik gösterim (URL-1), b) Kot farklarının gösterildiği külliye kesiti (A. Y1lmaz, 2001'den derlenmiştir.)

Külliyede cami, darüşşifa, sıbyan mektebi-darülhadis, medrese, imaret, tabhane, tekke (hankah), kervansaray ve hamam olmak üzere toplam 10 farklı yapı türü mevcuttur.

\subsubsection{Cami}

Külliyenin en yüksek kotuna 1571-1583 yılları arasında inşa edilen yapı, altı dayanaklı cami grubuna girmektedir (Kuran, 1988). Cami altıgen şeklinde merkezi planlı olarak inşa edilmiştir (Konyalı, 1977). Caminin harimini yaklaşık 12 metre çapındaki kubbe örterken her iki yanında 2'şer tane yarım ve tam kubbe mevcuttur. Cami, yaklaşık 56 x 43 m ölçülerinde dikdörtgen plan tipindedir. Yapının 5 kubbe ile örtülü son cemaat ve üst örtüsü kubbe olan sıralı revaklarla çevrelenmiş bir avlusu bulunmaktadir.

Avlu sınırlarını oluşturan revakların üst örtüsü 40 kubbeden oluşurken hünkar dairesinin eklenmesiyle 2 tanesi y1kılmıştır (Nemlioğlu, 2004). Toplam 3 adet giriş kapısı bulunan yapının ana girişi kuzey yönündeki taç kapıdan sağlanmaktadır.

Cami ve avlu beden duvarları kesme küfeki taşından; ana giriş kapısı, kemerler, mihrap ve minber ise beyaz mermerden inşa edilmiştir. Caminin tavan ve duvarlarında kalem işi bezemeler mevcuttur.

Kuban (1961) günümüz cami planının 4 aşamada meydana geldiğini belirtmektedir. $\mathrm{Bu}$ aşamaları da aşağıdaki şekilde belirtmiştir:

1. Caminin ilk yapımı,

2. Yan sahan ve son cemaat revaklarının eklenmesi,

3. Yan sahanların ileri çıkarılması,

4. Hünkar dairesi ve mahfelinin eklenmesi.

Kuran (1988) ise yan sahanların ileri çıkarılmasının farklı bir dönem olduğunu gösteren kanıtların olmamasından toplam 3 aşamadan oluştuğunu belirtmiştir (Kuran, 1988). Yap1 çeşitli dönemlerde onarımlar geçirmiş olsa da cami işlevini sürdürmektedir (Şekil 3).

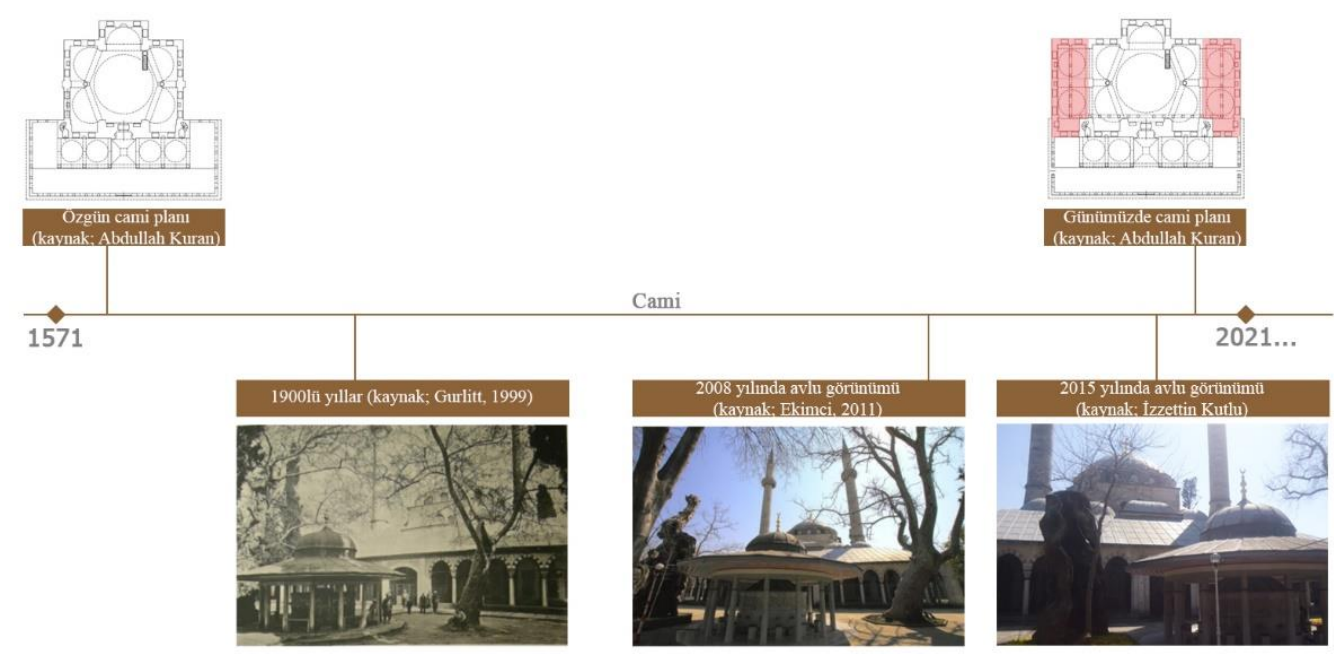

Şekil 3. Atik Valide Külliyesi - Caminin onarım dönemleri

\subsubsection{Darüş̧̧ifa}

Darüşşifa, İslam devletlerinde hastanelere verilen genel isimdir (Terzioğlu, 1992). Külliye'nin kuzeybatı yönünde konumlanmış olan darüşşifa, 1579 yılında tamamlanmıştır. Yapının ana girişi kuzey cephesindeki kemerli bir kapı iken dönemsel müdahalelerde tabhane ile arasında bulunan yola açılan bir kapı eklenmiştir (Eriş \& Yüzereroğlu, 2013; Katkak, 2016). Yap1 yaklaşık 35x45 metre ölçülerinde dikdörtgen planlı bir avlunun etrafına dizilmiş mekanlardan oluşmaktadır. Avlu yaklaşık $0.35 \mathrm{~cm}$ 'lik farka sahip iki ayrı kotta konumlanmıştır.
Avlunun etrafındaki mekanlar günümüzde 2 katlı olsa da yapının özgün halinin tek katlı ve kubbeli olduğu mevcut izlerden tespit edilebilmektedir. Avlu 20 kemerli bir revakla sınırlandırılmıştır.

Yapı beden duvarları kesme küfeki taşından, kubbe ve tonozlar tuğladan revakların oturduğu sütunlar ise mermerden inşa edilmiştir.

Yapı inşa edildiği dönemlerde tam teşekküllü bir hastane olarak işlev görmüştür. Sultan II. Mahmud döneminde Asâkir-i Hassa Toptaşı adıyla askeri hastane olarak kullanılmıştır. 1873 yılında yeniden işlevlendirilerek 1927 yılına kadar Toptaşı 
Bimarhanesi adıyla akıl hastanesi olarak kullanılmıştır. Bimarhane işlevi verildiği ilk yıllar olan 1874-1881 yılları arasında hasta sayısını kaldıracak kapasitede olmadığı için yeni bölümler eklenmiştir. Külliyenin darülhadis yapısı da bu yıllar arasında Bimarhane'nin bir bölümü olarak işlevlendirilmiştir. Kadın ve erkeklerin farklı koğuşlarda olduğu bimarhanenin hasta sayının artmasıyla her iki koğuş türüne de yeni eklemeler yapılmıştır. 1910 yılında kolera salgınının başlamasıyla âtıl duruma düşen bimarhaneye, 1922 yılında yeni bölümler eklenerek onarılmış ve bimarhane olarak kullanıma devam edilmiştir. 1927 yılında bimarhanenin Bakırköy'e nakledilmesiyle yapı ilk işlevine benzer şekilde hastane olarak kullanıma açılmıştır. Darüşşifa 1931 yılında Tekel Yaprak Tütün Bakım Atölyesi olarak işlevlendirilmiş ve 1976 yılına kadar bu şekilde kullanılmıştır. Atölyenin yer değiştirmesi sonucunda 1980-1999 yılları arasında Üsküdar İmam Hatip adıyla lise olarak kullanılmaya başlanmıştır. Yapı 2011 yılından beri Fatih Sultan Mehmet Üniversitesi Fen Edebiyat Fakültesi olarak kullanılmaktadır (Şekil 4, Artvinli, 2013; Ekimci, 2011; Yılmaz, 2001).

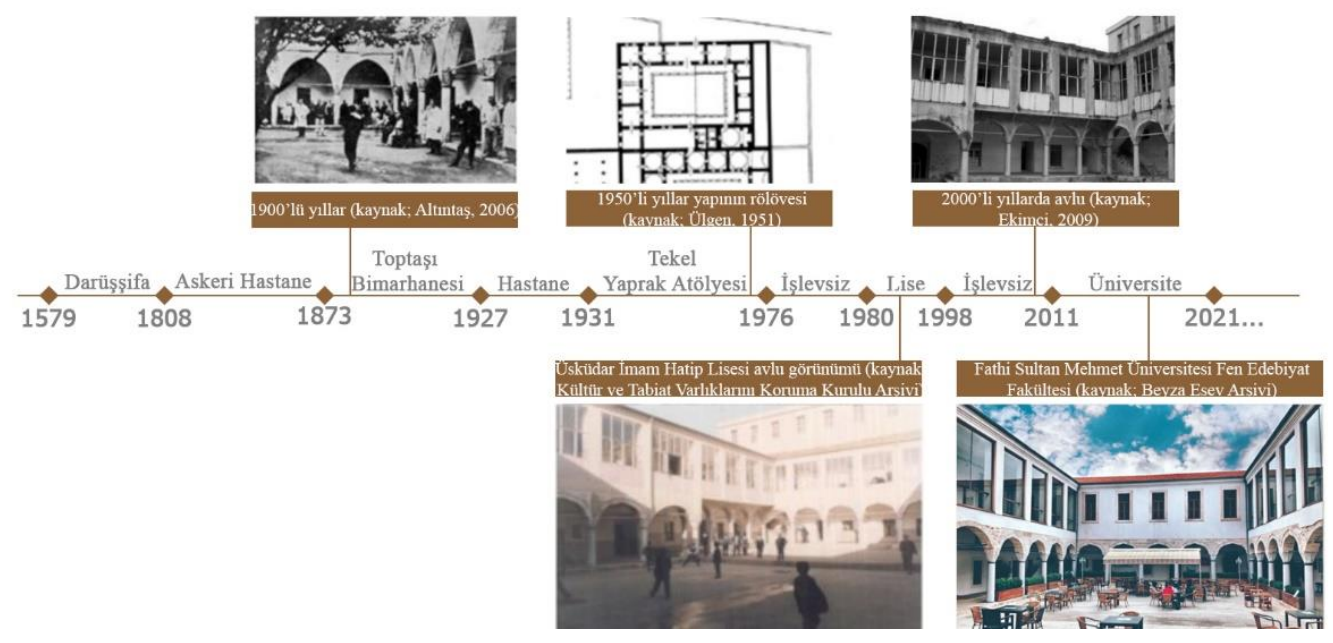

Şekil 4. Atik Valide Külliyesi - Darüşşifa yeniden işlevlendirilme dönemleri

\subsubsection{Sıbyan Mektebi-Darülhadis}

Sıbyan mektebleri özellikle dini eğitim ve Kur-an’1 Kerim dersi vermek amacıyla inşa edilen yapılardır. $\mathrm{Bu}$ yapılar külliyenin bir parçası olarak tasarlandıklarında, külliyenin en uç noktasına, girişi sokağa konumlandırılacak şekilde inşa edilmiştir. Buradaki amaç külliyedeki kişilerin çocuk sesinden rahatsız olmasını engellemektir (Dikmen ve Toruk, 2017; Yılmaz, 2009). Atik Valide Külliyesi'nin içindeki sıbyan mektebi ve darülhadis duvarları bitişik şekilde inşa edilmiştir. Kuzeybatı-güneydoğu aksında uzanan yapı bloğunun güneydoğu ucunda mektep bulunmaktadır. Yapı caminin güneybatısına, avlusu camiyi görecek şekilde inşa edilmiştir.

Mektep 18. yüzyıl başlarında kütüphane, 1873-1927 yılları arasında Toptaşı Bimarhanesi olarak işlevlendirilmiştir. Yaklaşık 20 yıllık dönemde işlevsiz kalan yapı 1950 yılında Toptaşı Cezaevi'nin bölümü olarak kullanılmıştır. Özellikle cezaevi olarak kullanıldığı dönemde önemli değişiklikler yapılıp özgün mimarisini genel anlamda yitiren yapının, 2017 yılında yeniden restorasyon çalışmalarına başlanmıştır (Şekil 5, Balcan, 2018; Ekimci, 2011).

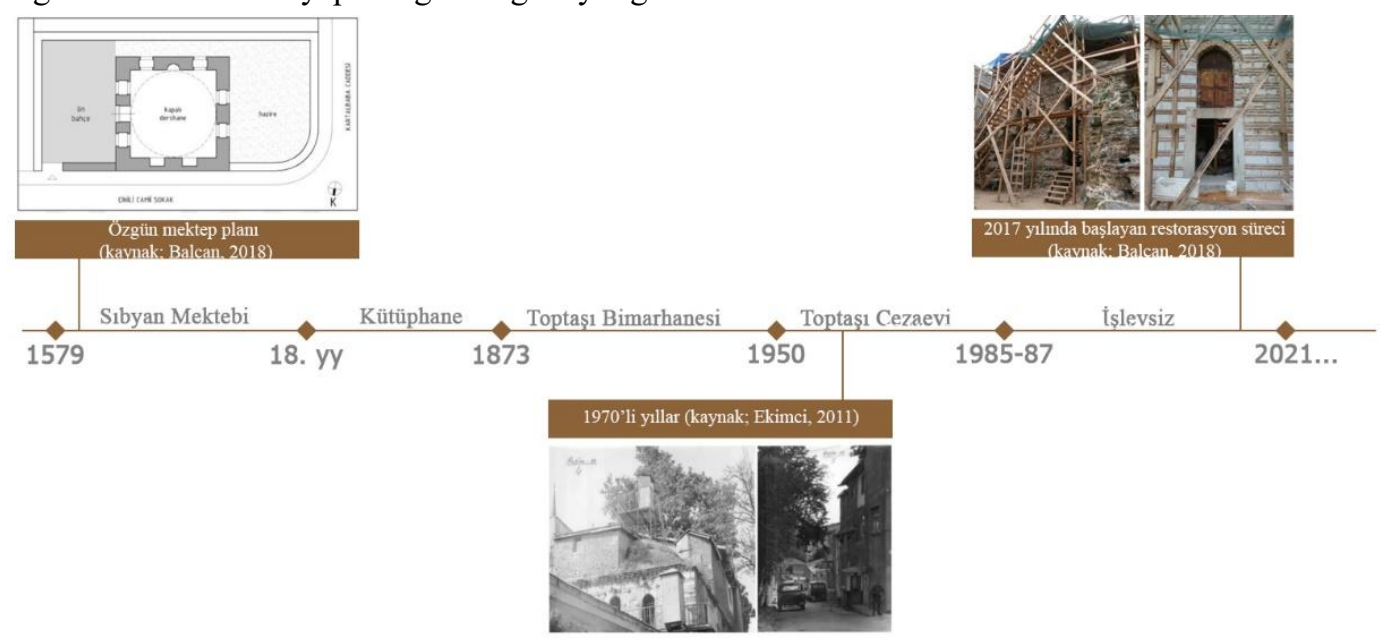

Şekil 5. Atik Valide Külliyesi - Sıbyan mektebi yeniden işlevlendirilme dönemleri

Darülhadis İslam ülkelerinde hadis eğitiminin verildiği yapılardır (Kalaç, 2020). Atik Valide Külliyesindeki darülhadise, cami avlusundan kemerli bir kapı ile girilmektedir. Girişin sağ ve solunda revaklı iki avlu mevcuttur. Revaklar sütunları birbirine bağlayan sivri kemerlerden oluşmaktadır. Revaklardan geçilerek ulaşılan sınıflar, birer kapı ve pencere ile avluya açılmaktadır. Yapının imaret ve darüşşifaya bakan cepheleri tuğla kemerlerle geçilmiş çift sıra pencerelerden oluşmaktadır.

Yapılan incelemelerde yapının tarihi kesin olmayan bir dönemde üstüne kat çıkıldığı ve üst örtüsünün tamamen yenilendiği tespit edilmiştir (Ekimci, 2011). 
Darülhadis 1873-1927 yılları arasında Toptaşı Bimarhanesi'nin erkekler koğuşunun bir bölümü olarak kullanılmıştır. Yapı 1950 yılında ise Toptaşı Cezaevi kullanımına tahsis edilmiştir (Ekimci, 2011; Yılmaz, 2001). 2011 yılında tezyini sanatlar kursu olarak işlevlendirilen yapı günümüzde İlim Kültür Araştırma ve Yardımlaşma Derneği olarak kullanılmaktadır (Şekil 6).

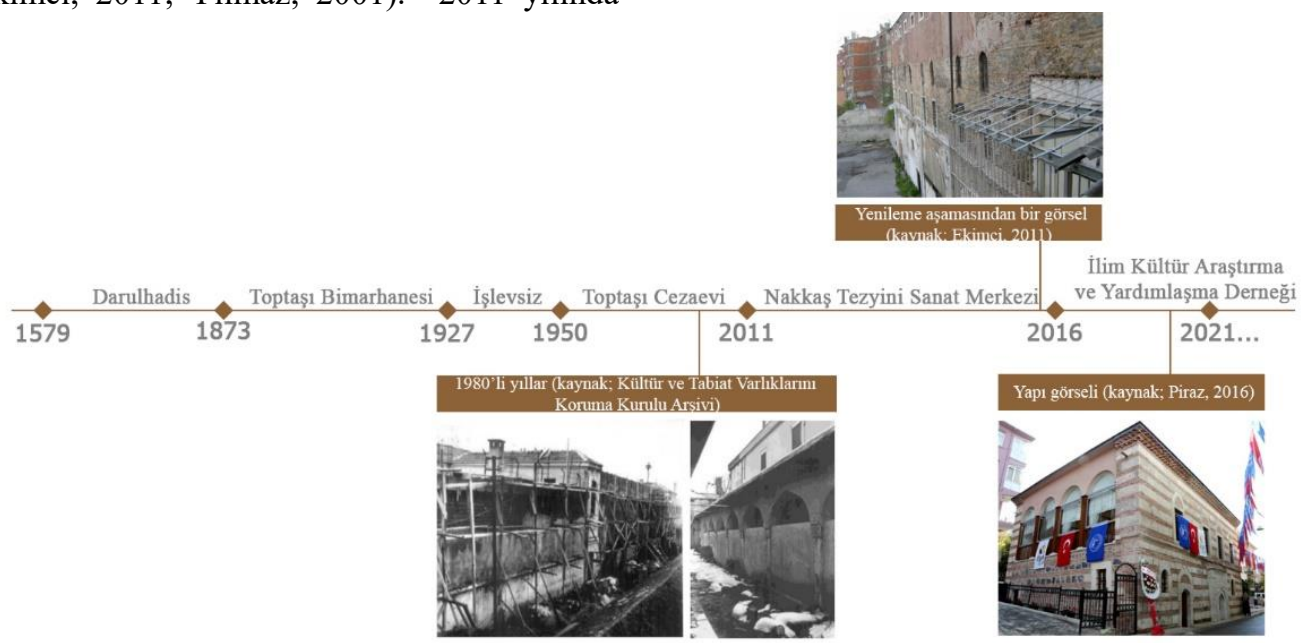

Şekil 6. Atik Valide Külliyesi - Darulhadis yeniden işlevlendirilme dönemleri

\subsubsection{Medrese}

Cami avlusunun kuzeyinde, 19 basamaklı merdiven ile inilen medrese avlusuna çapraz tonozlu kapıyla erişilmektedir. Medreseye ayrıca üç farklı kapıdan daha giriş sağlanmaktadır. Avlunun ortasında özgün halinde; saçaklı, sekizgen, mermer bir şadırvan ve cami avlu duvarına yakın bir kuyu bulunmaktadır. Medresenin, üç farklı yolun birleştiği parselde inşa edilmesi nedeniyle kuzeydoğu bölümü, güneybatı bölümüne oranla daha uzundur. Avlunun üç tarafinı saran 19 talebe odası ve bu odaların önünde toplamda 17 mermer sütunun taşıdığı, kubbeli revak bölümleri bulunmaktadır (Şekil 7).

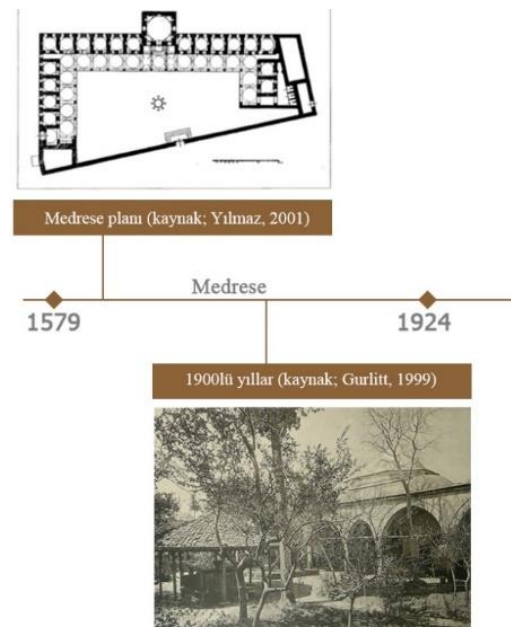

Şekil 7. Atik Valide Külliyesi- Medrese yeniden işlevlendirilme dönemleri
Yapı 1924 yılında medreselerin kapatılmasıyla işlevsiz kalmıştır. Uzun zaman bakımsız kaldığı bu süreç içerisinde en büyük fark, avlunun ortasında bulunan şadırvanda görülmüştür. Özgün durumunda ahşap ayaklı ve örtülü şadırvanın, örtüsü günümüzde bulunmamaktadır.

Yapı 2005 yılında özgün haline yakın bir şekilde restore edilerek İlim Yayma Cemiyetinin Kadıköy şubesi olarak yeniden işlevlendirilmiş ve günümüzde de aynı işlev ile kullanılmaktadır (Şekil 7; Yılmaz,2001).

\subsubsection{Imaret ve Tabhane}

İmaret; Osmanlı döneminde yoksullara, fakirlere ve bulunduğu yerdeki medrese öğrencilerine yiyecek dağıtan kurumdur. Bu kurum, günümüzde de halen devam eden bir kavram olan aşevi anlamında kullanılmıştır (Demir, 1998). Tabhane ise Osmanlı döneminde inşa edilen misafirhane yapılarıdır. $\mathrm{Bu}$ misafirhaneler, hasta, yorgun, işsiz vb. ihtiyaç sahibi kişilerin barındıkları yerlerdir (Erkan, 2005).
Atik Valide külliyesinde bulunan imaret yapısı, kuzeyinde tabhane ve güneyinde aşhane ile ortak kullanılan bir orta avludan oluşmaktadır. Cami-medrese aksına paralel ancak arazinin eğiminden daha alt kotta konumlandırılmıştır. İmaret yapısına, Toptaşı Caddesi üzerindeki kervansaray ile ortak bir kapıdan erişilmektedir. Avlunun üç kenarı revaklar ile çevrilidir. Orta avlunun kuzeyinde tabhane, güneyinde ise aşhane yer almaktadır ve her iki mekâna da basık kemerli kapılar ile erişilmektedir. Aşhanede, havalandırma fenerli 6 kubbe ile örtülmüş mutfak bulunmaktadır. Yemeklerin pişirildiği aşhane ile servis edildiği 
tabhane planları benzerlik gösterse de tabhane kubbeleri, ihtiyaç olmadığından fenersiz düzenlenmiştir.

1900'lü yılların başına kadar imaret yapısında, yemek pişmiş ve dağıtımı yapılmıştır. 1931 yılında darüşşifa yapısı ile imaret ve aşhaneyi oluşturan birimler Tekel Yaprak Tütün Bakım Atölyesine dönüştürülmüştür. $\mathrm{Bu}$ dönüşümün ardından yap1 1976 yılında Toptaşı Cezaevi olarak işlevlendirilmiş ve 1985 yılına kadar bu işlevle kullanıma devam edilmiştir. Yap1 1987

yılında ise İmam Hatip Lisesi olarak kullanıma açılmıştır. Bu kullanımlar sırasında, aşhanenin firınlarının yıkılması, bölücü duvar eklenmesi, revakların ve aşhane hücrelerinin kapatılması gibi yapının özgün durumunda hasarlara neden olabilecek büyük değişimler meydana gelmiştir (Ekimci, 2011). Bu müdahaleler neticesinde tabhanede bulunan baz1 revaklar tamamen yıkılmıştır. İmaret yapısı 2014 y1lı itibariyle Fatih Sultan Mehmet Vakıf Üniversitesi tarafından kullanılmaktadır (Şekil 8).

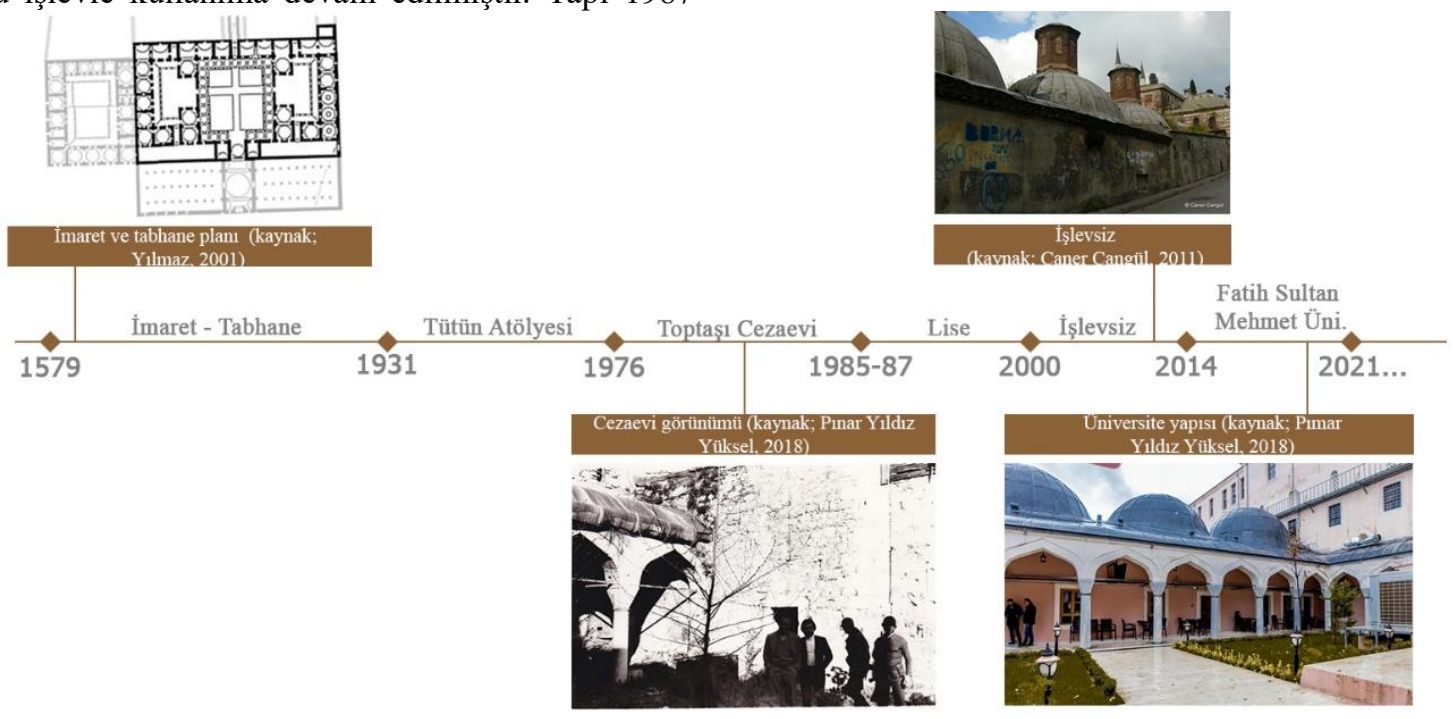

Şekil 8. Atik Valide Külliyesi - İmaret ve Tabhane yeniden işlevlendirilme dönemleri

\subsubsection{Tekke}

Tekke; aynı inanca bağlı kişilerin bir araya geldikleri, beraber barındıkları ve din eğitimi aldıkları yerlerdir (Kara, 2008). Bu yapılar da imarethaneler gibi Osmanlı Devleti zamanında yaşlı ve muhtaçlara yardım etme yeri olarak da kullanılmıştır (Öztürk, 2019). Atik Valide Külliyesi yapılarının en doğusunda, Valide Kahyası ve Tekkeönü Sokakları'nın birleşiminde tekke yapısı bulunmaktadır. Cami ve medrese yapısından bir sokakla ayrılan yapıda, parsel sınırları nedeniyle kuzey yönünde genişleyen yamuk planlı ve revaklar ile çevrili avlu mekanı bulunmaktadır. Yapıda mevcut 33 adet küçük oda ile bir adet büyük odanın tamamı kubbe ile örtülüdür.

Tekke, tarikatların yasaklandığı ve kapatıldığı 1925 yılına kadar özgün işlevine devam etmiştir. Ardından uzun süre bakımsız ve işlevsiz kalan tekke yapısı yoksul ve kimsesiz ailelerin barındığı bir yapıya dönüşmüştür (Ekimci, 2011). Vakıflar Genel Müdürlüğü tarafindan 1960'lı yıllarda restorasyon çalışması ile İlim Yayma Derneği Öğrenci Yurdu olarak işlevlendirilmiş ve 1980'li yıllara kadar aynı işlevle kullanılmıştır (Yılmaz, 2001). Yapı 2007 yılında 10 yıllığına Üsküdar Belediyesine devredilmiştir. Restorasyon projeleri tamamlanan yapı 2009 yılında Nakkaş Tezyini Sanatlar Merkezi olarak yeniden işlevlendirilmiştir (Ekimci, 2011). Dönüşüm süreçlerinde, geri dönüştürülemeyen en büyük hasarı avlunun merkezinde bulunan şadırvanın aldığı görülmektedir. Yapının 20.yüzyılın başlarına tarihlenen fotoğraflarında orta avluda şadırvan ve üzerini kapatan sundurma bir çatının olduğu ancak 1960'l1 yıllarda şadırvanın tamamen kaldırıldığ 1 tespit edilmiştir. Revakları ahşap doğramalı elemanlar ile kapatılan yapının, 2007 yılında hazırlanan restorasyon projeleri kapsamında özgün hali ile uyumlu bir dönüşüm gerçekleştirilmiştir (Şekil 9).

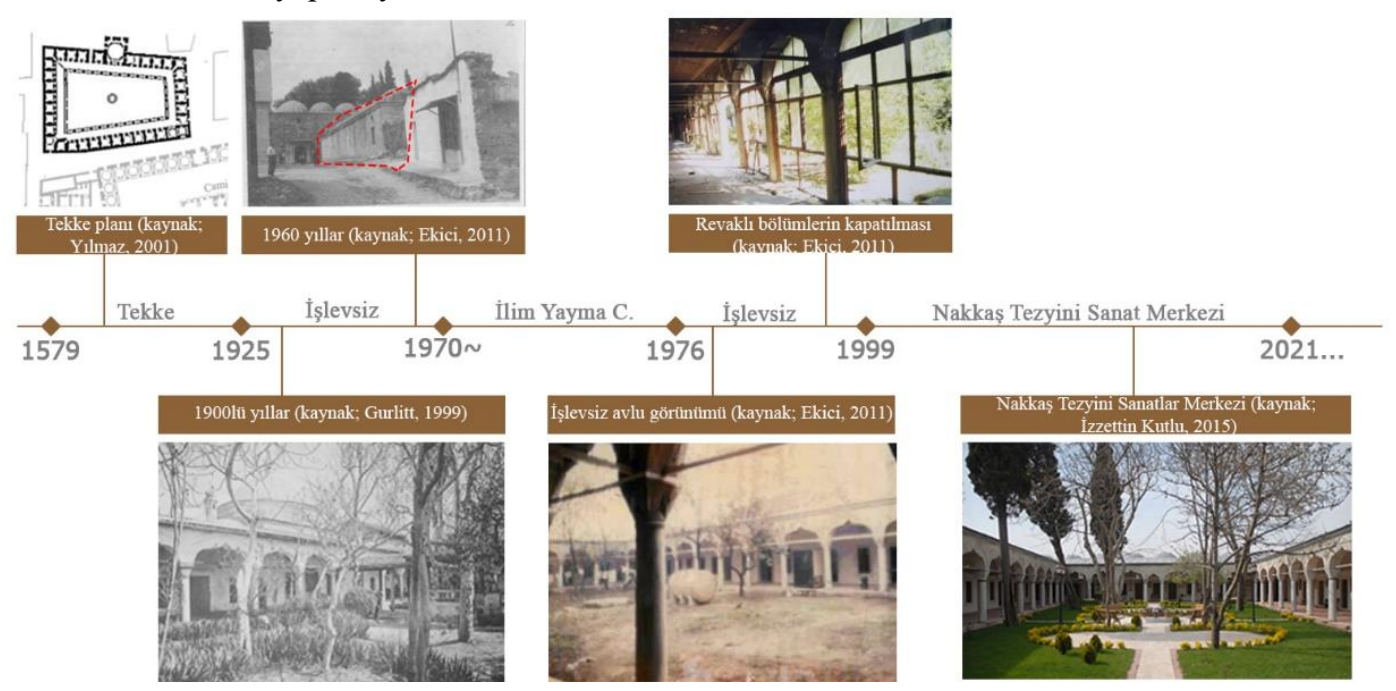

Şekil 9. Atik Valide Külliyesi - İmaret ve Tabhane yeniden işlevlendirilme dönemleri 


\subsubsection{Kervansaray}

Doğu ticaret yollarının İstanbul'a ulaştığı ilk merkez olan Üsküdar, aynı zamanda kervanların da Doğu'ya doğru hareket etmeye başladığı ilk yerdir. Bu özelliği sayesinde Üsküdar'ın ticari hayatını geliştirmek amacıyla bölgeye çok sayıda han ve kervansaray inşa edilmiştir. Ancak bunlardan günümüze ulaşan sadece Mimar Sinan'ın son eseri Atik Valide Külliyesinin kervansarayıdır. II. Mahmud, 1834 yılında Atik Valide Sultan külliyesinin darüşşifa ve kervansaray yapılarını restore ettirmiştir. Kervansarayın giriş kapısının önündeki iki sütunun taşıdığı saçak, Sultan Mahmud tarafindan yaptırılmıştır. Kervansarayın giriş kapısı Toptaşı Caddesi üzerinde yer almakta ve imaret girişi olarak da kullanılmaktadır (Yılmaz, 2001).

Kervansaraya giriş yapıldığında önce simetrik olarak yapıyı ikiye bölen ve etrafı duvarlarla çevrilmiş üzeri kubbe ve tonozlar ile örtülü taşlık mekanına erişilmektedir. Orta aksından simetrik olması nedeniyle 'çifte kervansaray' olarak da tanımlanmaktadır.

Özgün durumunda kuzey ve güney yönünde dikdörtgen formda bulunan iki kütleden oluşan kervansaray yapısı 19 . yüzyılda büyük değişikliklere uğramıştır. Kışla olarak kullanıldığı 1793-1865 yıllarında, yapının sadece dış beden duvarları korunmuş; her iki dikdörtgen planlı mekana avlu ve yeni bir kat eklenmiştir. Bu durum, yapının özgün durumu ile ilgili bilgilerin günümüze ulaşmasına engel olmuştur (Saraç, 2012). Bir dönem külliyenin diğer yapıları gibi Toptaşı Cezaevi olarak kullanılan yapı, bunun ardından uzun yıllar işlevsiz kalmıştır. Yap1 1976 yılında Vakıflar Genel Müdürlüğü tarafından Milli Eğitim Bakanlığı'na devredilmiş ve Üsküdar İmam Hatip Lisesi olarak kullanılmıştır (Ekimci, 2011). Günümüzde Fatih Sultan Mehmet Vakıf Üniversitesi tarafından eğitim yapısı olarak kullanılmaktadır (Şekil 10).

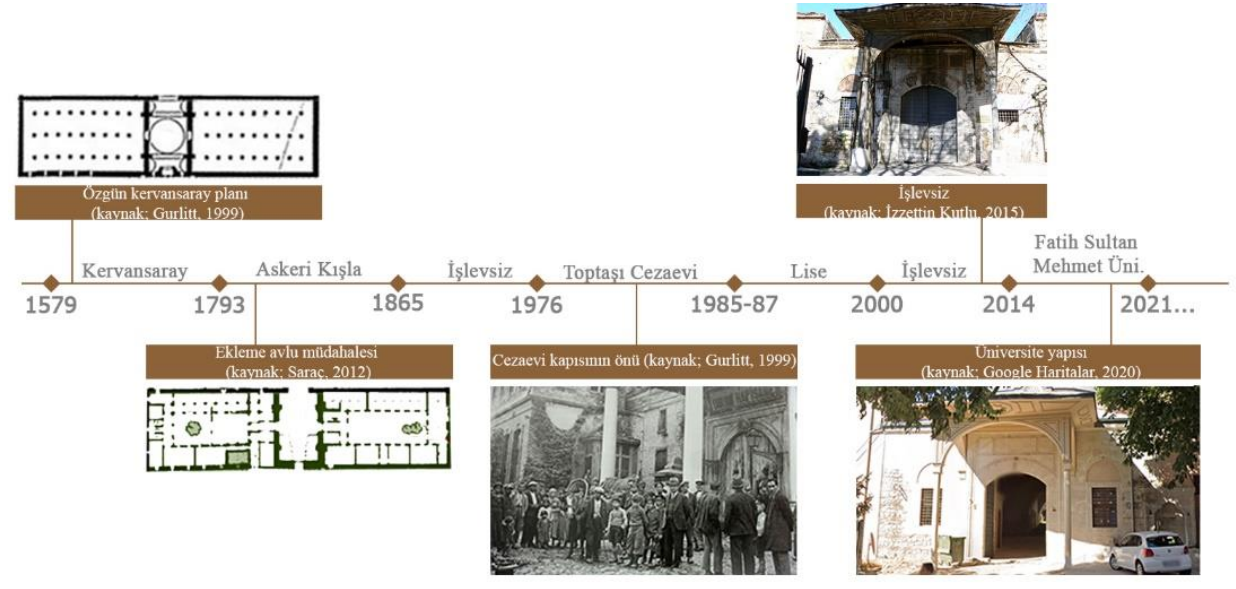

Şekil 10. Atik Valide Külliyesi - İmaret ve Tabhane yeniden işlevlendirilme dönemleri

\subsubsection{Hamam}

"Çifte hamam" olarak düzenlenmiş olan yapı, doğu-batı doğrultusunda simetrik olarak yerleştirilmiş soyunmalıklar, birer sofa ile halvetten oluşan soğukluk ve sıcaklıklardan oluşmaktadır. Toptaşı Caddesine cephesi olan soyunmalıklar, dükkan olarak kullanılmaktadır. Hamam, 1970'li yılların başına kadar marangoz atölyesi olarak kullanılmış ve Vakıflar İdaresi tarafindan 1985 yılında restore edilerek özgün işlevinde tekrar faaliyete geçirilmiştir (Şekil 16; Tanman, 1991).

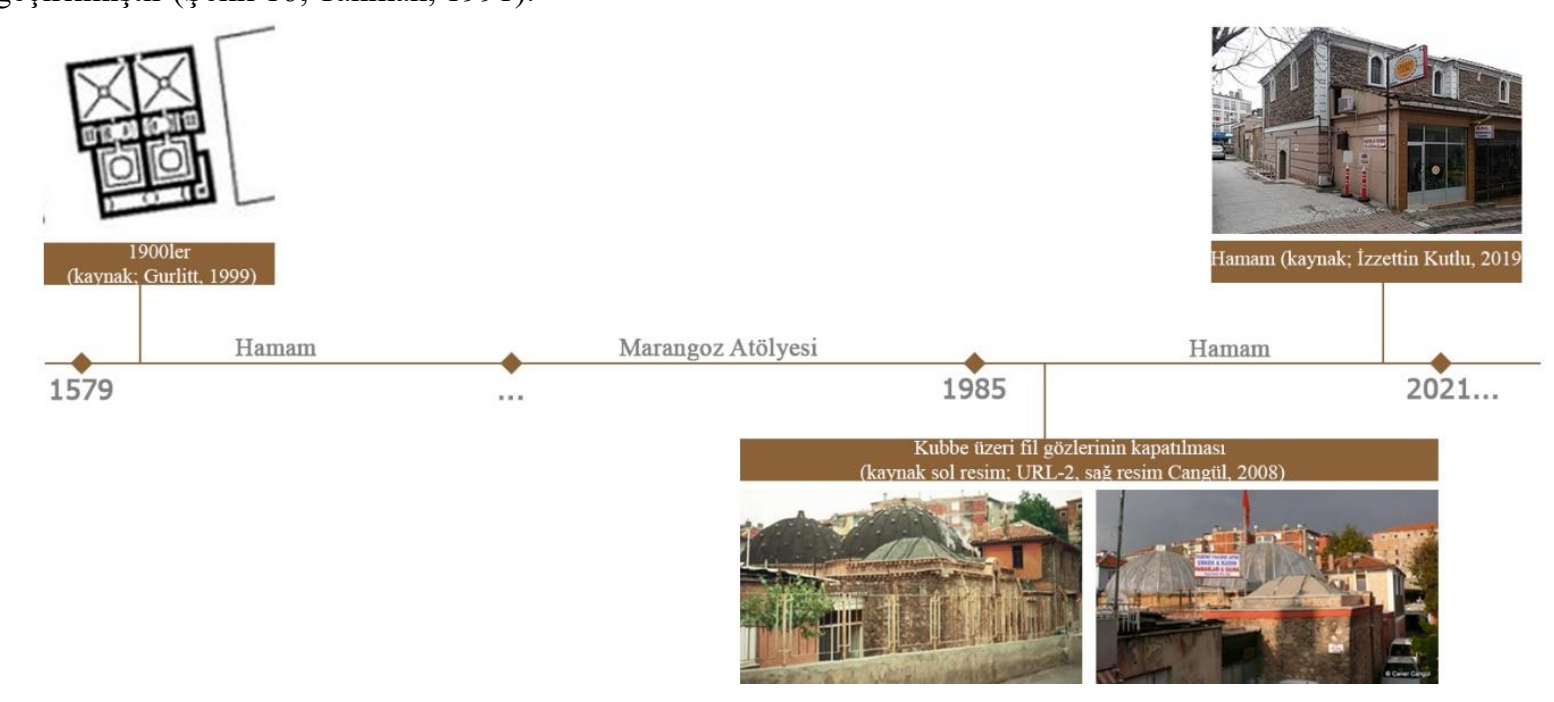

Şekil 11. Atik Valide Külliyesi - Hamam yapısının yeniden işlevlendirilme dönemleri
Yapılan restorasyon ve müdahale çalıșmalarında, fil gözleriyle aydınlatılan sıcaklık bölümünün üzeri kurşunla kaplanmıştır. Geniş, 1şıklı bir kubbenin kapattığ sıcaklık kısmında dört halvet, üç eyvan bulunmaktadır. Ortada sekizgen biçimli göbek taşı bulunmaktadır. Kadınlar kısmının sıcaklık duvarları mozaikle kaplanmıştır. Günümüzde işlevine uygun hizmet vermeye devam eden hamam, Toptaşı Hamamı, Valide Sultan Hamamı ve Orta Valide Hamamı olarak da bilinmektedir (Şekil 11). 


\section{Araştırma Sonuçları ve Tartışma}

Atik Valide külliyesinin birimleri uluslararası koruma ölçütleri bağlamında işlevsel, süreç ve çevresel analiz performans kriterlerine göre Tablo 2, 3, 4'te görüldüğ̈̈ șekilde değerlendirilmiş̧ir.

\section{1. İşlevsel Performans Değerlendirmesi}

Altınoluk (1998) tarihi bir yapıya verilen işlevin yapıya uygunluğunun araştırıldığı işlevsel performans değerlendirmesinde; yapının iç mekan ölçüleri, mekanların konumlanışı, mekanlar arası sirkülasyon kriterlerine dikkatedilmesi gerektiğini belirtmiştir.
Lutzkendorf vd. (2005) ise bu değerlendirme yapılırken yapı ve mekanlarının verilen işleve uygunluğu, mekanların esnekliği ve yapı kullanıcılarının mevcut yaşam koşullarına uygunluğuna dikkat edilmesi gerektiğini belirtmiştir.

Bu çalı̧̧mada külliye birimlerine inşa edildikleri dönemden günümüze kadar verilen çeşitli işlevlerin ilgili uluslararası koruma ölçütlerinin ilgili maddeleri bağlamında işlevsel performans değerlendirmeleri yapılmıştır. $\mathrm{Bu}$ bağlamda birimlere verilen işlevlerin günümüze kadar yapıya olumlu ve olumsuz etkileri değerlendirilmiştir (Tablo 2, Ek-1).

Tablo 2. Uluslararası koruma ölçütleri bağlamında külliye birimlerinin dönemsel işlevsel performans değerlendirmeleri

\begin{tabular}{|c|c|c|c|c|}
\hline \multirow[t]{2}{*}{ Kriter } & \multirow[t]{2}{*}{ Yapı } & \multicolumn{2}{|r|}{ Açıklama } & \multirow{2}{*}{$\begin{array}{l}\text { İlgili Uluslararası } \\
\text { Koruma Ölçütü }\end{array}$} \\
\hline & & Olumlu yaklaşım & Olumsuz yaklaşım & \\
\hline \multirow[t]{8}{*}{$\begin{array}{c}\text { İşlevsel } \\
\text { Performans }\end{array}$} & Cami & $\begin{array}{l}\text { - İnşa tarihinden günümüze } \\
\text { kadar gerçek işleviyle } \\
\text { kullanılması, }\end{array}$ & - & \multirow{8}{*}{$\begin{array}{l}\text { • Carta Del } \\
\text { Restauro-Madde } 4 \\
\text { •Venedik Tüzüğü- } \\
\text { Madde } 5 \\
\text { • ICOMOS } \\
\text { Geleneksel Mimari } \\
\text { Miras Tüzüğü } \\
\text { 1999-Uygulama } \\
\text { İlkeleri Madde } 1.5\end{array}$} \\
\hline & Darüşşifa & $\begin{array}{l}\text {-1873-1931 yılları arasındaki } \\
\text { işlev değişikliklerinde de sağlık } \\
\text { yapısı olarak kullanılması, }\end{array}$ & $\begin{array}{l}\text { • Özgün işlevi ile uyumlu olmayan; } 1931 \\
\text { y1lında Tekel yaprak ve tütün atölyesi, 1980'den } \\
\text { günümüze kadar ise eğitim yapısı olarak } \\
\text { kullanılması, }\end{array}$ & \\
\hline & $\begin{array}{l}\text { Sibyan Mektebi- } \\
\text { Darülhadis }\end{array}$ & $\begin{array}{l}\text { - 18. yy başında sıbyan } \\
\text { mektebinin gerçek işlevine } \\
\text { benzer olan kütüphane olarak } \\
\text { kullanılmış olması, } \\
\text { • Darülhadis'in günümüzde } \\
\text { gerçek işlevine yakın ilim kültür } \\
\text { araştırma ve yardımlaşma } \\
\text { derneği olarak kullanılması, }\end{array}$ & $\begin{array}{l}\text { Mektebin } 20 \text { yıl boyunca işlevsiz bırakılarak } \\
\text { terk edilmesi, ayrıca özgün işlevine uygun } \\
\text { olmayan bimarhane ve cezaevi olarak } \\
\text { işlevlendirilmesi, }\end{array}$ & \\
\hline & Medrese & $\begin{array}{l}\text { - Günümüzde özgün durumuna } \\
\text { yakın restore edilerek yeniden } \\
\text { işlevlendirilmesi, }\end{array}$ & $\begin{array}{l}\text { - } 1924 \text { yılında medreselerin kapatılması ile uzun } \\
\text { yıllar boyunca yapının işlevsiz kalması ve süreç } \\
\text { içerisinde avlunun ortasında bulunan şadırvanın } \\
\text { yıkılması, }\end{array}$ & \\
\hline & $\begin{array}{l}\text { İmaret ve } \\
\text { Tabhane }\end{array}$ & $\begin{array}{l}\text { • İmaret yapısı } 2014 \text { yılı } \\
\text { itibariyle Fatih Sultan Mehmet } \\
\text { Vakıf Üniversitesi tarafından } \\
\text { özgün durumuna uygun halde } \\
\text { restore edilerek yeniden } \\
\text { işlevlendirilmesi, }\end{array}$ & $\begin{array}{l}\text { - Yapıların özgün durumuna uygun olmayan } \\
\text { yeniden işlevlendirilmeleri sonucunda; } \\
\text { aşhanenin firınlarının yıkılması, denetimsiz } \\
\text { onarımlar uygulanması, bölücü duvarlar } \\
\text { eklenmesi, aşhane hücrelerinin uyumsuz } \\
\text { müdahalelere maruz bırakılması, bazı revakların } \\
\text { kapatılarak kapı ve pencere elemanlarının } \\
\text { uygulanması gibi yapının özgün durumunda } \\
\text { hasarlara neden olabilecek büyük değişimler } \\
\text { meydana getirilmesi, }\end{array}$ & \\
\hline & Tekke & $\begin{array}{l}\text { - Yapının } 2007 \text { yılında } \\
\text { hazırlanan restorasyon projeleri } \\
\text { kapsamında özgün haline uygun } \\
\text { bir dönüşüm ile yeniden } \\
\text { işlevlendirilmesi, }\end{array}$ & $\begin{array}{l}\text { - } 1925 \text { yılına kadar özgün işlevine devam eden } \\
\text { yapının. tekkelerin kapatılması ile fakir ailelerin } \\
\text { barındığı bir yapıya dönüştürülmesi, } \\
\text { • Bu dönüşüm sırasında revak bölümlerinin } \\
\text { kapatılması ve şadırvanın özgün üst örtüsünün } \\
\text { yıkılması, }\end{array}$ & \\
\hline & Kervansaray & - & $\begin{array}{l}\text { - Kışla olarak kullanıldığı dönemde yapının } \\
\text { sadece dış beden duvarlarının korunması; özgün } \\
\text { durumu ile uyumlu olmayan, her iki dikdörtgen } \\
\text { planlı mekana avlu ve yeni bir kat eklenmesi, }\end{array}$ & \\
\hline & Hamam & $\begin{array}{l}\text { - Uzun yıllar farklı işlevlerde } \\
\text { kullanılan yapının, } 1985 \text { yılında } \\
\text { özgün işlevi ile yeniden } \\
\text { kullanılmaya başlanması, }\end{array}$ & $\begin{array}{l}\text { • Kubbede, fil gözleriyle aydınlatılan sıcaklık } \\
\text { bölümünün üzerinin kurşun ile kaplanması, } \\
\text { • Soyunmalıkların betonarme olarak iki kat } \\
\text { halinde özgün durumuna uygun olmadan inşa } \\
\text { edilmesi, } \\
\text { • Kadınlar kısmının sıcaklık duvarlarının } \\
\text { mozaikle kaplanması, }\end{array}$ & \\
\hline
\end{tabular}




\subsection{Süreç Performans Değerlendirmesi}

Lützkendorf vd. (2005) bir yapının süreç performans değerlendirmesini, yapının inşa edildiği dönemden itibaren, mimari plan ve projesinde meydana gelen değişimlerin incelendiği en önemli performans değerlendirme kategorilerinden biri olarak açıklamaktadır.

Ergün ve Halaç (2021) yapmış oldukları çalışmada yapının süreç performansının değerlendirilmesinde projelendirme ve onarım kriterlerini baz almıştır. Yapının inşa edildiği tarihten günümüze kadar olan değişimlerin yapı gerçeklerine uygunluğunu rölöve, restitüsyon ve restorasyon projeleri bağlamında analiz etmiştir.

Bu çalışmada külliye birimlerinin inşa edildikleri dönemden günümüze kadar yapılan onarım, yenileme, terk edilme gibi durumlarda yapıda meydana gelen değişimlerin literatür taramaları ve dönem görselleri baz alınarak ilgili uluslararası koruma ölçütlerinin ilgili maddeleri bağlamında süreç performans değerlendirmeleri yapılmıştır. $\mathrm{Bu}$ bağlamda geçmişten günümüze birimlerde meydana gelen değişimlerin yapıya olumlu ve olumsuz etkileri değerlendirilmiştir (Tablo 3, Ek-1).

Tablo 3. Uluslararası koruma ölçütleri bağlamında külliye birimlerinin dönemsel süreç performans değerlendirmeleri

\begin{tabular}{|c|c|c|c|c|}
\hline \multirow[t]{2}{*}{ Kriter } & \multirow[t]{2}{*}{ Yapı } & \multicolumn{2}{|r|}{ Açıklama } & \multirow{2}{*}{$\begin{array}{l}\text { İlgili } \\
\text { Uluslararası } \\
\text { Koruma } \\
\text { Ölçütü }\end{array}$} \\
\hline & & Olumlu yaklaşım & Olumsuz yaklaşım & \\
\hline \multirow[t]{8}{*}{$\begin{array}{c}\text { Süreç } \\
\text { Performans }\end{array}$} & Cami & $\begin{array}{l}\text { - Yapı iç mekan sirkülasyonunu } \\
\text { olumsuz yönde etkileyecek } \\
\text { seviyede bir değişikliğin } \\
\text { yapılmaması, }\end{array}$ & $\begin{array}{l}\text { - Yapıda yıkım yapılarak yan sahan ve son cemaat } \\
\text { yeri gibi eklemelerin yapılmış olması, } \\
\text { - Yapılan değişikliklerin yapının inşa edildiği ilk } \\
\text { plan özelliklerinde önemli değişikliklere neden } \\
\text { olması ve bu değişikliklerin yapı gerçek planının } \\
\text { nasıl olduğuna dair anlaşmazlıkların dahi } \\
\text { oluşmasına sebep olması, } \\
\text { - Yapılan onarımların özgünden ayırt edilememesi, } \\
\text { - Yapı dış mekan duvarında kararma ve } \\
\text { bitkilenmelerin meydana gelmesi, } \\
\text { • Yeterli düzeyde önlem alınmaması sonucu } \\
\text { çalınan çinilerin yerine yapı tarihine uygun } \\
\text { olmayan çinilerin eklenmesi, } \\
\text { - Yapılan onarımların özgünden ayırt edilememesi, }\end{array}$ & \multirow[t]{8}{*}{$\begin{array}{l}\text { • Carta Del } \\
\text { Restaura- } \\
\text { Madde 1, 7, } 9 \\
\text { • Venedik } \\
\text { Tüzüğ̈̈- } \\
\text { Madde } 12 \\
\text { - Washington } \\
\text { Tüzüğü } \\
\text { Madde } 8\end{array}$} \\
\hline & Darüşşifa & - & $\begin{array}{l}\text { - Yapının giriş kapısı kemerlerinin yok edilmiş } \\
\text { olması, } \\
\text { • Yapıya verilen yeni işlevler sonucunda işleve } \\
\text { uygun yeni bir giriş kapısının açılması, } \\
\text { • Yeni işlev yeterliliği için üst kat ve çeşitli } \\
\text { bölümlerin eklenmiş olması, } \\
\text { - Yapıya uygun işlev seçiminin aksine verilen } \\
\text { işleve göre tarihi yapının şekillendirilmiş olması, } \\
\text { • Yapı duvarlarının tarihi yapı malzemesine uygun } \\
\text { olmayan boyayla boyanmış olması, } \\
\text { • Yapıya plastik yağmur iniş boruları ve } \\
\text { tabelaların eklenmesi, }\end{array}$ & \\
\hline & $\begin{array}{l}\text { Sibyan Mektebi- } \\
\text { Darülhadis }\end{array}$ & - & $\begin{array}{l}\text { - Sıbyan mektebinin özellikle cezaevi olarak } \\
\text { kullanımı sırasında önemli mimari değişikliklerin } \\
\text { yapılmış olması, }\end{array}$ & \\
\hline & Medrese & $\begin{array}{l}\text { - Yeniden işlevlendirilme } \\
\text { süreçlerinde yapının strüktürel } \\
\text { olarak hasar görmemesi, }\end{array}$ & - Şadırvana ait taşıyıcıların yıkılması, & \\
\hline & $\begin{array}{l}\text { İmaret ve } \\
\text { Tabhane }\end{array}$ & - & $\begin{array}{l}\text { - Bazı revaklı bölümlerin tamamen yıkılması } \\
\text { sonucu yapının strüktürel olarak dayanımının } \\
\text { azalma ihtimali, }\end{array}$ & \\
\hline & Tekke & $\begin{array}{l}\text { - Taşıyıcı elemanların özgün } \\
\text { olmayan eklerden } \\
\text { arındırılması, }\end{array}$ & $\begin{array}{l}\text { - Revaklı bölümlere yapılan eklemeler sonucunda } \\
\text { taşıyıcı sisteminin hasar görmesi, }\end{array}$ & \\
\hline & Kervansaray & $\begin{array}{l}\text { - Yapıda önemli değişikliklerin } \\
\text { yapıldığı sırada dış beden } \\
\text { duvarlarının korunması, }\end{array}$ & $\begin{array}{l}\text { - Yapının kışla amacı ile dönüştürüldüğ̈u sürede, } \\
\text { sadece dış beden duvarlarının korunarak iç mekan } \\
\text { taşıyıcılarının tamamen ortadan kaldırılması ve } \\
\text { yeniden iki katlı bir yapının inşa edilmesi, }\end{array}$ & \\
\hline & Hamam & - & $\begin{array}{l}\text { - Yapı ile strüktürel olarak uyumlu olmayan } \\
\text { betonarme eklemelerin yapılması, }\end{array}$ & \\
\hline
\end{tabular}




\section{3. Çevresel Performans Değerlendirmesi}

Yapı fiziksel çevre biçimlendirilmesinde dolaşım alanları, erişim olanakları, trafik yoğunluğu ve otopark sayısı gibi değerler göz önünde bulundurulmalıdır (Dikmen ve Özçetin, 2016). Bir yapının çevresel performansının değerlendirilmesinde de çeşitli araştırmacıların belirlemiş olduğu bu gibi kriterler mevcuttur.

Lützkendorf vd. (2005) yapının çevresel performansını, yapının çevresi ile olan uyumu ve karşılıklı etkileşimi olarak açıklamaktadır. Yapının çevresel performansı değerlendirilirken hem yakın hem uzak çevrenin dikkate alınması ve yapının arazi kullanımı, trafik ve yapı yoğunluğu ve kaynak kullanımı gibi verilere dikkat edilmesi gerektiğini belirtmiştir.
Yaldız (2013) bir yapının çevresel performansını değerlendirirken, yapının doğal ve yapılı çevre ile ilişkisi, çevrenin tarihi özellikleri ile olan bağı ve yapı erişilebilirliği gibi kriterlere dikkat edilmesi gerektiğini belirtmiştir.

Ergün ve Halaç (2021) ise yapmış oldukları çalışmada, bir yapının çevresel performansının değerlendirilmesinde yapıya ulaşım ve kentsel mekan oluşumu gibi kriterleri baz almıştır.

Bu çalışmada külliyenin birimleri bir bütün olarak ele alınıp yapının çevresiyle olan uyumu alan çalışması, literatür taramaları ve yapı görselleri baz alınarak ilgili uluslararası koruma ölçütlerinin ilgili maddeleri bağlamında çevresel performans değerlendirmesi yapılmıştır (Tablo 4, Ek-1).

Tablo 4. Uluslararası koruma ölçütleri bă̆lamında külliye birimlerinin dönemsel çevresel performans değerlendirmeleri

\begin{tabular}{|c|c|c|c|c|}
\hline \multirow[t]{2}{*}{ Kriter } & \multirow[t]{2}{*}{ Yapı } & \multicolumn{2}{|c|}{ Açıklama } & \multirow{2}{*}{$\begin{array}{l}\text { İlgili } \\
\text { Uluslararası } \\
\text { Koruma } \\
\text { Ölçütü }\end{array}$} \\
\hline & & Olumlu yaklaşım & Olumsuz yaklaşım & \\
\hline \multirow{8}{*}{$\begin{array}{l}\text { Çevresel } \\
\text { Performans }\end{array}$} & Cami & \multirow{8}{*}{$\begin{array}{l}\text { - Yaya ve taşıt ulaşımının uygun } \\
\text { olması, } \\
\text { - Bulunduğu yer için tanıtm } \\
\text { elemanı olması, }\end{array}$} & \multirow{8}{*}{$\begin{array}{l}\text { - Yapıların restorasyon ve yeni } \\
\text { işlevlerinin belirlenmesinde bir bütün } \\
\text { olarak ele alınmaması, } \\
\text { - Trafik yoğunluğunun fazla olması } \\
\text { sonucu titreşim ve gürültü oranının } \\
\text { artması, } \\
\text { • Otopark sayısının yetersiz olması } \\
\text { sonucu araçların yollara park ederek } \\
\text { geçişlere engel olması, } \\
\text { - Yapının yakın çevresi ile renk, ölçü, } \\
\text { oran ve işlev bütünlüğünün } \\
\text { sağlanmaması, } \\
\text { - Külliyenin yakın çevresinde çöp } \\
\text { alanlarının oluşması ve yeterli } \\
\text { seviyede çevre düzenlemesinin } \\
\text { yapılmamış olması, } \\
\text { - Yapı yakın çevre yaya yollarında } \\
\text { bozulmaların meydana gelmiş olması, }\end{array}$} & \multirow{8}{*}{$\begin{array}{l}\cdot \text { Carta Del } \\
\text { Restaura- } \\
\text { Madde } 6 \\
\text { • Venedik } \\
\text { Tüzüğü- Madde } \\
6,13,14\end{array}$} \\
\hline & Darüşşifa & & & \\
\hline & $\begin{array}{l}\text { Sibyan Mektebi- } \\
\text { Darülhadis }\end{array}$ & & & \\
\hline & Medrese & & & \\
\hline & $\begin{array}{l}\text { İmaret ve } \\
\text { Tabhane }\end{array}$ & & & \\
\hline & Tekke & & & \\
\hline & Kervansaray & & & \\
\hline & Hamam & & & \\
\hline
\end{tabular}

\section{Sonuç}

Somut kültürel mirası temsil eden tarihi yapılar, geçmişe ait kültürel, mimari, sanatsal ve bilimsel özellikleri taşıyan önemli kimlik unsurlarıdır. Dolayısıyla korunmaları, geçmiş ile gelecek arasında anlamlı bağlantılar kurulmasına katkı sağlayacak ve bulunduğu bölgede aidiyet duygusunu arttıracaktır. Güçlendirme, bütünleme, yeniden yapma, temizleme gibi birçok farklı tekniği bulunan restorasyon, tarihi yapıların korunmasında önemli rol oynamaktadır.

Çalışmada, tarihi yapıların korunması sırasında uygulanan restorasyon tekniklerinin olumlu ve olumsuz yaklaşım değerlendirilmesi, Mimar Sinan'ın son eseri olarak bilinen Atik Valide Külliyesi özelinde ele alınmıştır. Külliye yapılarının işlevsel, süreç ve çevresel performans değerlendirmesi Carta Del Restauro (1931), Venedik Tüzüğü (1964), Washington Tüzüğü (1987), Burra Tüzüğü (1999) ve ICOMOS Geleneksel Mimari Miras Tüzüğü 1999-Uygulama İlkeleri kapsamında ortaya konmuştur. Dönemler içerisinde birçok müdahale ve dönüşüm geçiren külliye yapılarının, özgün durumuna kalıcı hasar veren olumsuz yaklaşımlar bulunduğu gibi özgün durumuna benzerlik gösterecek şekilde korunarak günümüze ulaşmasının sağlandığ olumlu yaklaşımların da bulunduğu görülmektedir. $\mathrm{Bu}$ yaklaşımların ortaya konduğu çalışmanın, külliye yapıları için yapılacak olan bilimsel veya uygulamalı çalışmalarda kaynak olması hedeflenmektedir. Yapılan değerlendirme yöntemi çok sayıda medeniyete ev sahipliği yapan İstanbul şehri özelinden hareketle, yeniden işlevlendirme sürecinde ve uygulanacak müdahalelerin değerlendirilmesinde bir yaklaşım ve örnek oluşturabilir. Ayrıca işlevsel değişimlerin kronolojik sıralama yapılarak analiz edildiği çalışma, yerel yönetimlere ön analiz için bir metod önerisi olarak sunulmaktadır. Bu analiz sonucunda tarihi yapıların belgelendirilerek özgün durumuna en yakını tespit edilmekte ve uyumlu müdahalelerde bulunulabilmektedir.

İnşa edildiği dönemden günümüze özellikleri ortaya konan tarihi Atik Valide Külliyesi yapılarının; fonksiyonel ve kütlesel değişiminin detaylı olarak incelenmesi arşiv niteliğinde olup mimari koruma alanına bir katkı olarak sunulmaktadır. $\mathrm{Bu}$ kapsamda, geçmişin somut kültür ürünü olarak bir yapının tarihi değerleri açıkça tanımlanmalı ve yeniden işlevlendirilme süreçlerinde binanın ilk inşa durumuna uygun korunurken kendi döneminin kimliğini de taşıyacak uyumlu işlevler belirlenmelidir. $\mathrm{Bu}$ bağlamda, yapılacak müdahalelerin özgün durumundan ayırt edilebilir olması ve tarihi binanın özelliklerini koruması büyük önem taşımaktadır.

Not: Bu çalışma İzzettin Kutlu adlı yazarın Ahmet Sever ile ortak çalışması olan "Geçmişten Günümüze Başı Beladan Kurtulmayan Mimar Sinan'ın Son Eseri; Atik Valide Külliyesi, 
Prof. Dr. Gönül Tankut Anısına Sempozyumu Koruma Geçmiş, Bugün, Gelecek Arasındaki Diyalog, Ankara" poster sunumundan genişletilmiştir.

\section{Kaynakça}

Artvinli, F. (2013). Delilik Siyaset ve Toplum: Toptaşı Bimarhanesi 1873-1927. Boğaziçi Üniversitesi Yayınevi.

Ahunbay, Z. (1988a). Mimar Sinan Yapılarında Kullanılan Yapım Teknikleri ve Malzeme.

Ahunbay, Z. (1988b). Mimar Sinan'ın Eğitim Yapıları. Mimarbaşı Koca Sinan Yaşadığı Çağ ve Eserleri, 1, 239-309.

Akgün, G. H. (2005). 16. yy. Osmanlı kenti İstanbul'da kent içi konumlarına göre Mimar Sinan'ın külliye gruplarında yer seçimi etmenlerinin tespiti ve analizi. (Yayımlanmamış yüksek lisans tezi) Süleyman Demirel Üniversitesi Fen Bilimleri Enstitüsü, Isparta.

Alaboz, M. (2008). Mimar Sinan köprülerinin güncel durum değerlendirmesi ve Kapuağası köprüsü restorasyon projesi. (Yayımlanmamış yüksek lisans tezi). İstanbul Teknik Üniversitesi Fen Bilimleri Enstitüsü, İstanbul.

Alkan, G. (2007). İstanbul Mimar Sinan Dönemi Külliyeleri İçinde Medreselerin Yeri ve 'Edirnekap1 Mihrimah Sultan Medresesi'. (Yayımlanmamış yüksek lisans tezi). Yıldız Teknik Üniversitesi Fen Bilimleri Enstitüsü, İstanbul.

Altınoluk, Ü. (1998). Binaların yeniden kullanımı. İstanbul: YEM Yayınları

Altıntaş, S. (2020, 19 Şubat). Mimar Sinan'ın Son Şarkısı: Valide-i Atik Külliyesi. Hürriyet. Website: https://www.hurriyet.com.tr/seyahat/mimar-sinanin-son-sarkisivalide-i-atik-kulliyesi

Balcan, C. (2018). Mimar Sinan'ın İstanbul külliyelerinde yer alan sibyan mektepleri ve koruma sorunları [Mimar Sinan Üniversitesi]. https://tez.yok.gov.tr/UlusalTezMerkezi/tezSorguSonucYeni.jsp

Benli, G. (2016). Hospitals in the Ottoman Period and the Work Of Sinan the Architect: Suleymaniye Külliye Dar Al-Shifa and the Medical Madrasa. A+ Arch Design International Journal of Architecture and Design, 2(3), 1-9.

Bennett, A. \& Elman, C. (2006). "Complex causal relations and case study methods: The example of path dependence", Political analysis, 250-267.

Britannica, T. Editors of Encyclopaedia (2020). Sinan. Encyclopedia Britannica. https://www.britannica.com/biography/Sinan

Cangül, C. (2008). Atik Valide Hamamı. https://www.canercangul.com/16493/atik-valide-hamami/ adresinden 25 Şubat 2021 tarihinde erişildi.

Çıplak, E. L. (2017). Mimar Sinan yapılarının inşa tekniğini anlamak: Lüleburgaz Sokullu Mehmed Paşa Camisi örnek çalışması. (Yayımlanmamış doktora tezi). Orta Doğu Teknik Üniversitesi Fen Bilimleri Enstitüsü, Ankara.

Demir, M. (1998). Türkiye Selçuklu şehirlerinde imaret kurumları ve vakıfları. Vakıflar Dergisi, 27, 53-73.

Demirdal, M. (2014). İstanbul'da işlev değişikliğine uğramış Mimar Sinan Hamamları: Ortaköy hamamı örneği. (Yayımlanmamış yüksek lisans tezi). Bahçeşehir Üniversitesi Fen Bilimleri Enstitüsü, İstanbul.

Dikmen, Ç.B. ve Özçetin, Z (2016). Herkes için Tasarım Kapsamında bir Avrupa Birliği Gençlik Projesi Deneyimi: Engelsiz Yozgat. Avrupa Bilim ve Teknoloji Dergisi, 4(7), 5874.

Dikmen, Ç.B. ve Toruk, F. (2017). Sıbyan Mekteplerinin Mimarisi: Abdullah Paşa Sıbyan Mektebi Örneği. Vakıflar Dergisi, 48, 35,73 .

Dinçel, I. (1995). İstanbul'daki Mimar Sinan dönemi medreseleri genel değerlendirmesi ve Kılıç Ali Paşa Medresesi.
(Yayımlanmamış yüksek lisans tezi). Yıldız Teknik Üniversitesi Fen Bilimleri Enstitüsü, İstanbul.

Ekimci, B. G. (2011). Üsküdar'ın Vakıf Eser Kültür Mirası Ve Korunması İçin Öneriler. İstanbul Teknik Üniversitesi.

Eriş, İ., \& Yüzereroğlu, U. (2013). Atik Valide Sultan Külliyesi 2011-2013 yılları restorasyonu ve uygulamaları. Içinde Vakıf Restorasyon Yıllığ

Ergün, R., \& Halaç, H. H. (2021). Kırkkaşık Bedesteni'nin Yapı Kullanıcıları Bazında Kullanım Sonrasında Değerlendirilmesi. Online Journal of Art and Design, 9(3), 150-162. http://adjournal.net/articles/93/9312.pdf. Erişim Tarihi: 15.02 .2021

Erkan, G. (2005). Tabhane. Toplum ve Sosyal Hizmet, 16(2), 53-56.

Ertuğrul, A. D. (2002). Mimar Sinan'ın İstanbul'daki mevcut hamamları. (Yayımlanmamış yüksek lisans tezi). İstanbul Teknik Üniversitesi Fen Bilimleri Enstitüsü, İstanbul.

İpekçi, E. (2016). Mimar Sinan tarafından İstanbul'da inşa edilen Çinili Hamam'ın sıva özellikleri. (Yayımlanmamış yüksek lisans tezi). İzmir Yüksek Teknoloji Enstitüsü Mühendislik ve Fen Bilimleri Enstitüsü, İzmir.

İşçi E. (2008). "Nitel araştırma yöntemleri", http://emreisci.blogspot.com.tr/2008/11/nitel-aratirmayntemleri.html, adresinden 25 Şubat 2021 tarihinde erişildi.

Kalaç, R. (2020). Bir Hadis İhtisas Kurumu Olarak Nûriyye Ve Eşrefiyye Dârülhadisi. Türkiye Din Eğitimi Araştırmaları Dergisi, 9, 67-82. https://dergipark.org.tr/tr/download/articlefile/1173094

Kara, M. (2008). Tekke eğitimi ve literatürü. Türkiye Araştırmaları Literatür Dergisi, 6(12), 107-138.

Karagöz, Ș. (2005). Marmaray Projesi Üsküdar Meydanı Aç-Kapa İstasyonu Arkeolojik Kurtarma Kazıları. 15. Müze Çalışmaları ve Kurtarma Kazıları Sempozyumu, 137-166.

Katkak, B. (2016). Mimar Sinan'in İstanbul'u. Türkiye Turing ve Otomobil Kurumu.

Kaygısız, A. (2019). Mimar Sinan Camilerinden Şemsi Ahmet Paşa Camii (Üsküdar) ile T.C. Diyanet İşleri Başkanlığı Tip 3 Camii'nin akustik açıdan karşılaştırılması. (Yayınlanmamış Yüksek Lisans Tezi). İstanbul Teknik Üniversitesi Fen Bilimleri Enstitüsü, İstanbul.

Kaynar, İ. C. (2019). Restorasyon uygulamaları sonrasında önleyici koruma metodolojisinin Mimar Sinan dönemi türbeleri üzerinde irdelenmesi. (Yayımlanmamış yüksek lisans tezi). Yıldız Teknik Üniversitesi Fen Bilimleri Enstitüsü, İstanbul.

Konyalı, İ. H. (1977). Abideleri ve Kitabeleriyle Üsküdar Tarihi. Türkiye Yeşilay Cemiyeti.

Kuban, D. (1961). Atik Valide Camii. Mimarlık ve Sanat, 2.

Kuran, A. (1988). Mimar Sinan'ın Camileri. Içinde S. Bayram (Ed.), Mimarbaşı Koca Sinan: Yaşadığı Çağ ve Eserleri-1 (ss. 175214). Vakıflar Genel Müdürlüğü. http://hdl.handle.net/11352/1771

Kutlu, İ. \& Sever, A. (2017). Geçmişten Günümüze Başı Beladan Kurtulmayan Mimar Sinan'ın Son Eseri; Atik Valide Külliyesi, Prof. Dr. Gönül Tankut Anısına Sempozyumu Koruma Geçmiş, Bugün, Gelecek Arasındaki Diyalog, Ankara.

Lutzkendorf, T., Speer, T., Szigett1, F., Davis, G., Roux, P.C., Kato, A., Tsuekawa, K. (2005). A comparison of international classifcations for performance requirements and building performance categories used in evaluation methods, CIB 2005 Helsinki Symposium, International Council for Research and Innovation in Building and Construction, Helsinki

Nemlioğlu, C. (2004). Üsküdar, Atik Valide Camii Özgün Kalem İşleri Ve Türk-İslam Bezeme Sanatındaki Yer. Içinde Z. Kurşun, A. E. Bilgili, K. Kahraman, \& C. Güngör (Ed.), Üsküdar Sempozyumu I (ss. 59-89). Üsküdar Belediye Başkanlığı Üsküdar Araştırmaları Merkezi. https://www.uskudar.bel.tr/userfiles/files/1.sempozyum_cilt_2.p df 
Öztürk, T. (2019). Huzurevlerinde yatak odası mekanının gelişim süresi, İstanbul ve Brüksel Örneği. Avrupa Bilim ve Teknoloji Dergisi, 16, 662-678

Polat, M. (2020). Mimar Sinan dönemi camileri içerisinde yer alan Diyarbakır İskender Paşa Caminin önemi ve koruma sorunları. (Yayımlanmamış yüksek lisans tezi). Dicle Üniversitesi Fen Bilimleri Enstitüsü, Diyarbakır.

Rabb, P. (2013) 'We are all servants here!' Mimar Sinan - architect of the Ottoman Empire, Periodica Polytechnica Architecture, 44(1), pp. 17-37. https://doi.org/10.3311/PPar.7444

Saraç, T. (2012). Şehirleşen Üsküdar'da Ticaret Olgusu ve Mekânsal Oluşuma Etkisi, 7 . Uluslararası Üsküdar Sempozyumu, 251-266.

Sadan, O. B., Bal, I. E. and Smyrou, E. (2007). Structural Analysis of Istanbul Beyazit II Mosque Retrofitted by Mimar Sinan. In Proceedings of the International Symposium on Studies on Historical Heritage.

Sekitmez, K. M. (2019). İstanbul Mimar Sinan dönemi medreseleri ve Üsküdar Mihrimah Sultan medresesi koruma ve işlev sorunları. (Yayımlanmamış yüksek lisans tezi). Yıldız Teknik Üniversitesi Fen Bilimleri Enstitüsü, İstanbul.

Sönmez, Ü. N. (2010). Mimar Sinan yapısı menzil külliyelerinden; İzmit Pertev Paşa Külliyesi. (Yayımlanmamış yüksek lisans tezi). Sakarya Üniversitesi Sosyal Bilimler Enstitüsü, Sakarya.

Sönmez, E. S. (2015). Mimar Sinan'ın Şehzade, Süleymaniye ve Selimiye Camilerindeki birim hücrelerden üreyen geometrik desenlerin çözümlemeleri. (Yayımlanmamış yüksek lisans tezi). Marmara Üniversitesi Sosyal Bilimler Enstitüsü, İstanbul.

Symon, G. E. \& Cassell, C. E. (1998). Qualitative methods and analysis in organizational research: A practical guide. Sage Publications Ltd.
Tuncer, S. (2014). Mimar Sinan camilerinde kubbenin akustik açıdan belgelenmesi: Kadırga Sokollu Mehmet Paşa camii örneği. (Yayımlanmamış yüksek lisans tezi). Anadolu Üniversitesi Fen Bilimleri Enstitüsü, Eskişehir.

Tanman, M. B. (1991). Atik Valide Sultan Külliyesi. Içinde Türkiye Diyanet Vakfi İslam Ansiklopedisi (C. 4, ss. 68-73).

Terzioğlu, A. (1992). Darüşşifa. Içinde Türkiye Diyanet Vakfı İslam Ansiklopedisiİslam Ansiklopedisi (ss. 163-178). Türkiye Diyanet Vakfi. https://islamansiklopedisi.org.tr/bimaristan

URL-1. https://www.sanatinyolculugu.com/uskudar-atik-validesultan-kulliyesi/ (Erişim Tarihi: 08.11.2020)

\section{URL-2.} https://www.uskudar.bel.tr/tr/main/erehber/hamamlar/41/validei-atik-hamami-toptasi-hamami/405 (Erişim Tarihi: 11.08.2020)

Yaldız, E. (2013). Anıtsal Yapıların Kullanım Sürecinde Değerlendirilmesine Yönelik Bir Model Önerisi, Doktora Tezi, Selçuk Üniversitesi Fen Bilimleri Enstitüsü

Yandex Haritalar, Website: https://yandex.com.tr/harita/115706/uskudar/?1l=29.023987\%2 C41.018821\&mode $=$ search\&oid $=1071022895 \&$ ol $=$ biz\&z $=17.9$ 6 (Erişim Tarihi: 08.11.2020)

Yağlı, B. M. (2010). Mimar Sinan'ın Şehzade, Süleymaniye ve Selimiye camilerinin tektonik karakterlerinin çözümlenmesi. (Yayımlanmamış doktora tezi). Gazi Üniversitesi Fen Bilimleri Enstitüsü, Ankara.

Yıldırım, A. (1999). Nitel Araştırma Yöntemlerinin Temel Özellikleri ve Eğitim Araştırmalarındaki Yeri ve Önemi, Eğitim ve Bilim, 23(112).

Yılmaz, A. (2001). Osmanlı mimarisinde külliye olgusu ve Atik Valide Külliyesi örneği. Mimar Sinan Üniversitesi.

\section{Ekler}

\section{Ek-1: Çalışma kapsamına alınan uluslararası koruma ölçütlerinin ilgili maddeleri}

\begin{tabular}{|c|c|}
\hline Kriter & İlgili Uluslararası Koruma Ölçütü \\
\hline \multirow[t]{3}{*}{$\begin{array}{l}\text { İsslevsel } \\
\text { Peformans }\end{array}$} & $\begin{array}{l}\text { "Carta Del Restauro (1931) Madde 4: Yaşayan, yani ayakta duran anıtlara, yalnızca özgün işlevinden çok uzak olmayan ve binada gerekli uyarlamaların önemli hasara neden olmayacak } \\
\text { șekilde yapılabileceği yeni kullanır verilmesi kabul edilebilir" }\end{array}$ \\
\hline & $\begin{array}{l}\text { "Venedik Tüzüğ̈̈ (1964) Madde 5: Kültür varlı̆ının korunması, her zaman onları herhangi bir yararlı toplumsal amaç için kullanmakla kolaylaştırılabilir. Bunun için bu tür bir kullanma arzu } \\
\text { edilir, fakat bu nedenle yapının planı, ya da beze-meleri değiștirilmemelidir. Ancak bu sınırlar içinde yeni işlevin gerektirdiği değişiklikler tasarlanabilir ve buna izin verilebilir." }\end{array}$ \\
\hline & $\begin{array}{l}\text { "ICOMOS Geleneksel Mimari Miras Tüzüğü (1999) Uygulama ilkeleri Madde 1.5: Geleneksel yapıların yeni işlevlere uyarlanması ve yeniden kullanımında, yapılar kabul edilebilir bir } \\
\text { yaşam standardna yükseltilirken, bütünlüğü, karakteri ve biçimi saygı görmelidir. Eğer geleneksel mimari biçimler hala kullanıllyorsa, müdahaleler toplumun kabul edeceği bir etik kurallar } \\
\text { çerçevesinde yapılabilir." }\end{array}$ \\
\hline \multirow[t]{5}{*}{$\begin{array}{l}\text { Sürec } \\
\text { Performans }\end{array}$} & $\begin{array}{l}\text { "Carta Del Restauro (1931) Madde 1: Herşeyden önce, anıta, çökme ve aşınmalardan ötürü kaybettiği dayanıklılı̆̆ ve zamana karşı direnme gücünü yeniden kazandırmaya yönelik sürekli } \\
\text { bakım ve sağlamlaşırma çabalarına önem verilmesi gerekir." }\end{array}$ \\
\hline & $\begin{array}{l}\text { "Carta Del Restauro (1931) Madde 7: Eğer bir anıtı sağlamlaştırmak, kısmi veya tam olarak bütünlemek amacıyla, ya da yeniden kullanım nedeniyle ekler yapılması gerekirse, uyulması } \\
\text { gereken temel koşul yeni öğelerin en az da tutulmaları, yalın ve yapısal düzeni yansitır karakterde olmalarıdır benzer üslupta bir ek ancak yapının } \\
\text { mevcut çizgilerini devam ettirmek ve bezemeden arınmış geometrik anlatımlar söz konusu olduğunda kabul edilebilir." }\end{array}$ \\
\hline & $\begin{array}{l}\text { "Carta Del Restauro (1931) Madde 9: Bir anttın taşıııcı sistemini güçlendirmek veya kütlesini bütünlemek için eski yapım yöntemleriyle amaca ulaşılmazsa, çağdaş tekniklerin kullanılması } \\
\text { uygun olabilir. Aynı biçimde, basit ya da karmaşı tüm yıpranmış strüktürleri ayakta tutabilmek için çeșitli bilimlerin katkıda bulunmaya } \\
\text { çağrılması gerekir. Böylece bilime dayanmayan yöntemler yerlerini bilimsel olanlara bırakmak zorundadır." }\end{array}$ \\
\hline & $\begin{array}{l}\text { "Venedik Tüzüğ̈̈ (1964) Madde 12: Eksik kısımlar tamamlanırken, bütünle uyumlu bir şekilde bağdaştırıl-malıdır; fakat bu onarımın, aynı zamanda sanatsal ve tarihi tanıklı̆ı yanlış bir } \\
\text { biçim-de yansıtmaması için, özgünden ayırt edilebilecek bir şekilde yapılması gereklidir." }\end{array}$ \\
\hline & $\begin{array}{l}\text { "Washington Tüzïğü (1987) Madde 8: Yeni isslev ve etkinlikler tarihi kent veya kentsel alanın karakteriyle uyumlu olmalıdır. Bu alanların çağdaş yaşama uyarlanması için gerekli teknik } \\
\text { servislerin getirilmesi veya iyileştirilmesi işlemleri özenle yapılmalıdır." }\end{array}$ \\
\hline \multirow[t]{8}{*}{$\begin{array}{l}\text { Çevresel } \\
\text { Performans }\end{array}$} & $\begin{array}{l}\text { "Carta Del Restauro (1931) Madde 6: Anıta ve geçirdiği dönemlere olduğu kadar çevresine de saygilı olunmalıdır. Anıtın çevresindeki yapılar yikılarak uygunsuz bir biçimde yalnız } \\
\text { bırakılmasna veya çevresinin niteliği, kütlesi, rengi, üslubu ile rahatsız edici yapılarla sarılmasına engel olunmalıdır. }\end{array}$ \\
\hline & $\begin{array}{l}\text { "Venedik Tüzü̈̆ğ (1964) Madde 6: Kültür varllğının korunması, ölçeği dışına taşmamak koşuluyla çevresinin de bakımını içine almalıdır. Eğer gelenek-sel ortam varsa, olduğu gibi } \\
\text { bırakılmalıldır. Kütle ve renk ilişkilerini değiştirecek hiçbir yeni eklentiye, yok etmeye ya da değiştir-meye izin verilmemelidir." }\end{array}$ \\
\hline & $\begin{array}{l}\text { "Venedik Tüzüğg̈ (1964) Madde 13: Eklemelere, ancak yapının ilgi çekici bölümlerine, geleneksel konumuna, kompozisyonuna, dengesine ve çevresiyle olan bağıntısına zarar gelmediği } \\
\text { durumlar-da izin verilebilir. }\end{array}$ \\
\hline & $\begin{array}{l}\text { "Washington Tüzüğü (1987) Madde 2: Korunması istenen nitelikler kentin veya kentsel alanın tarihi karakteri ile bu karakteri } \\
\text { olussturan maddi ve tinsel bileșenlerdir, özellikle: } \\
\text { a. Parsel ve sokakların tanımladığı kent dokuları, } \\
\text { b. Binalarla yeșil ve açık alanlar arasındaki ilişkiler, } \\
\text { c. Binaların ölçek, boyut, üslup, yapım tekniği, kullanılan malzemeler, renk ve bezemeler ile tanımlanan biçimleri, iç ve dış görünüşleri, } \\
\text { d. Kent veya kentsel alanın doğal ve insan yapisı çevresi ile arasındaki ilişki; } \\
\text { e. Kent veya kentsel alanın zaman içinde yüklendiği değişik işlevler. } \\
\text { Bu özellikleri tehdit eden olumsuz etkenler tarihi kent veya kentsel alanın özgünlüğünü zedeleyebilir. }\end{array}$ \\
\hline & $\begin{array}{l}\text { "Washington Tüzüğ̈̈ (1987) Madde 10: Yeni binalar yapıılması gerektiğinde veya eskileri uyarlanırken, mevcut mekansal oluşum saygı görmeli, özellikle ölçek ve parsel boyutuna dikkat } \\
\text { edilmelidir. Çevreye uyumlu çağdaş ögeler yöreyi zenginleştirebileceğinden, yeni tasarımlar engellenmemelidir." }\end{array}$ \\
\hline & "Washington Tüzüğü (1987) Madde 12: Tarihi bir kent veya kentsel alandaki trafik denetlenmeli, park alanları tarihi dokuyu veya çevresini zedelemeyecek şekilde düzenlenmelidir." \\
\hline & "Washington Tüzüğ̈̈ (1987) Madde 13: Kent veya bölge planlarının öngördüğü yeni otoyollar, tarihi kente veya kentsel alana sokulmamalı, fakat tarihi kente ulaşımı kolaylaştırmalıdır. \\
\hline & $\begin{array}{l}\text { Burra Tüzüğü: Kültürel Öneme Sahip Yerlerin Korunması Amaçıl Avustralya-ICOMOS Tüzüğü. (1999) Madde 8: Tarihi bir alanın korunması, görsel düzenlemeleri } \\
\text { ve tarihi dokuya katkıda bulunan diğer parçalarının da korunmasını } \\
\text { beraberinde getirir. Nitekim yeni yapılanma, yıkım, izinsiz müdahaleler } \\
\text { veya ortamı olumsuz yönde etkileyecek diğer değişiklikler uygun değildir” }\end{array}$ \\
\hline
\end{tabular}

